\title{
Portfolio Preferences of Foreign Institutional Investors
}

\author{
Reena Aggarwal \\ McDonough School of Business \\ Georgetown University \\ Washington D.C. 20057 \\ (202) 687-3784 \\ aggarwal@georgetown.edu \\ Leora Klapper \\ The World Bank \\ 1818 H Street, NW \\ Washington D.C. 20433 \\ (202) $473-8738$ \\ 1klapper@worldbank.org \\ Peter D. Wysocki \\ Sloan School of Management \\ Massachusetts Institute of Technology \\ Cambridge, MA 02139 \\ (617) 253-6623 \\ wysockip@mit.edu
}

\section{World Bank Policy Research Working Paper 3101, July 2003}

The Policy Research Working Paper Series disseminates the findings of work in progress to encourage the exchange of ideas about development issues. An objective of the series is to get the findings out quickly, even if the presentations are less than fully polished. The papers carry the names of the authors and should be cited accordingly. The findings, interpretations, and conclusions expressed in this paper are entirely those of the authors. They do not necessarily represent the view of the World Bank, its Executive Directors, or the countries they represent. Policy Research Working Papers are available online at http://econ.worldbank.org.

We thank Asli Demirguc-Kunt, Bill Droms, George Comer, Christian Leuz, Keith Ord, and seminar participants at American University, University of Alabama, University of Florida, Georgetown, Fortis-Georgia Tech Conference on International Finance, London Business School, Penn State, University of Texas-Austin AIM Investment Center Conference, and The World Bank for helpful comments. Emily Drogt, Volkan Muslu, Victor Sulla, Christen Cuculich, Nobuyuki Kobayashi and Aya Okajima provided excellent research assistance. We also thank I/B/E/S for providing analyst data. Aggarwal gratefully acknowledges research support from the Graduate School of Arts and Sciences and the McDonough School of Business, Georgetown University. 


\title{
Portfolio Preferences of Foreign Institutional Investors
}

\begin{abstract}
This paper examines investment allocations in emerging markets by actively-managed U.S. mutual funds. We analyze both country- and firm-level characteristics and policies that influence these investment allocations. At the country-level, we find that U.S. funds invest more in open emerging markets with stronger shareholder rights, legal frameworks and accounting policies. After controlling for country characteristics, U.S. funds are found to invest more in large, growing firms with high analyst following and policies such as an ADR listing and more transparent accounting policies. The impact of an ADR listing and better accounting policies is most pronounced in countries with weaker investor protection. Our results suggest that steps can be taken both at the country- and the firm-level to create an environment conducive to foreign institutional investment.
\end{abstract}




\section{Portfolio Preferences of Foreign Institutional Investors}

This paper examines the active investment allocations of U.S. mutual funds in emerging market equities. We focus on emerging markets because foreign capital plays an important role in promoting economic growth in countries with developing financial systems. ${ }^{1}$ Moreover, emerging markets exhibit wide variation in country-level and firm-level policies that potentially affect foreign investment flows. Our analysis provides new insights into the country and firm characteristics and policies that influence U.S. institutional investment decisions. We find that (a) country-level policies such as floating exchange rates and strong shareholder rights, legal institutions, and accounting standards, and (b) firm-level characteristics such as greater growth options, size, and analyst following and policies such as ADR listing and better accounting disclosures are associated with greater U.S. mutual fund investment. In addition, the impact of the ADR listing and accounting disclosures is most pronounced in countries with weak shareholder rights.

Our finding that country and firm-level discretionary policies affect institutional investment in emerging markets is relevant to the on-going debate on governance reforms in global markets. U.S. institutions, including mutual funds, constitute the largest source of equity capital in the world. Both emerging market firms and countries are interested in attracting U.S. institutional investment to improve individual stock and overall market liquidity. This additional demand lowers firms' cost of capital and allows them to compete more effectively in the global marketplace, hence benefiting a country's economy. In addition, previous research finds a strong link between capital market development and economic growth. ${ }^{2}$

\footnotetext{
${ }^{1}$ Allayannis, Brown and Klapper (2003) and Esty (2003) show the importance of foreign debt for emerging market firms.

${ }^{2}$ For example see Levine (1997), King and Levine (1993a, 1993b) and Rajan and Zingales (1998).
} 
The focus of our analysis is on the investment allocation strategies of U.S. fund managers. ${ }^{3}$ We use a unique combination of databases to examine these investment allocation decisions, including fund-level investment allocations from Morningstar ${ }^{4}$; firm-level financial and accounting information from Worldscope; firm-level and country-level market performance data from Datastream; and country-level data from the IMF-IFS database and other published sources. This data allows us to test the impact of country and firm-level policies and their interactive effect on U.S. mutual fund managers' investment allocations.

Our sample and methodology provide unique insights into the major factors that influence institutional investment allocations. First, we focus on the link between the outside demand for information and firms' and countries' policies. Unlike other classes of institutional investors, mutual funds generally do not engage in active firm-level corporate governance activities. Therefore, our mutual fund sample allows us to isolate the role of countries' and firms' "arms-length" governance policies on foreign investment decisions. Second, in contrast to prior related research, we analyze funds' investment allocations that deviate from passive investment strategies that mirror major market indices. ${ }^{5}$ We use a sample of actively-managed emerging market mutual funds that do not simply track a benchmark index. However, the benchmark index is important because fund managers' performance-based compensation is generally tied to a benchmark index. We use the Morgan Stanley Capital International (MSCI) Emerging Markets Free Index as the benchmark for investment allocations in emerging markets. The MSCI Index is a widely-used measure of emerging market performance and is often used as a benchmark for

\footnotetext{
${ }^{3}$ Previous literature has studied the portfolio allocation choices of mutual funds across asset classes (Elton and Gruber, 2003). However, to the best of our knowldege, this is the first cross-country study of firm-level fund investments.

${ }^{4}$ Prior mutual fund studies typically use the CDA/Spectrum database to obtain portfolio holdings in U.S. firms. However, portfolio holdings in non-U.S. firms is only available from the Morningstar database.
} 
fund managers' performance-based compensation. Perfect tracking of the index is typically neither feasible nor desirable by actively managed funds. In addition to explicit decisions to deviate from the index, managers may use stratified and optimization sampling and synthetic replication to duplicate the index. We perform all empirical analyses in both absolute terms and relative to the MSCI index.

Our descriptive evidence shows that while there is considerable overlap between the U.S. fund holdings and the MSCI Emerging Markets Index, the funds do not limit their investments to stocks in the Index. The Index includes 649 firms in 2001, but our sample of actively-managed U.S. mutual funds invested in twice that number of emerging market firms in 2001. In addition, some of the firms included in the Index are not part of the funds' holdings.

We first examine the relationship between U.S. mutual fund investments and countrylevel characteristics. We are particularly interested in discretionary policies that can lead to greater foreign investment flows. ${ }^{6}$ La Porta el al. $(1997,1998,2000)$ find that strong investor protection laws, high enforcement and high quality accounting disclosures lead to greater financial and capital market development. We test these country-level measures as possible determinants of U.S. mutual fund investment allocations. Our results show that U.S. mutual funds are more likely to invest in equities in emerging market countries that have floating exchange rate policies and better shareholder rights, legal institutions, and average accounting quality. In addition, we find that the impact of average firm-level accounting disclosures on U.S. investment allocations is higher in countries that have weak shareholder rights.

\footnotetext{
${ }^{5}$ In particular, firm and market attributes such as size and liquidity are systematically related to index membership. Therefore, a finding that U.S. funds "actively" invest in larger and more liquid stocks and markets may simply reflect the funds' passive indexing strategy.

${ }^{6}$ For example, Gelos and Wei (2002) and Borensztein and Gelos (2001) study the behavior of international portfolio flows over time. Kaminsky, Lyons, and Schmukler (2001) examine the relationship between portfolio flows and stock returns. In addition, see Froot, O'Connell, and Seasholes (2001), and Brennan and Cao (1997).
} 
Next, we examine the relationship between mutual fund investment and firm-level characteristics and discretionary policies. Our results show that U.S. mutual funds allocate more of their assets to large growth firms with high analyst following and low leverage. In addition to these characteristics, we focus on firms' discretionary policy choices that potentially attract foreign investment in spite of the institutional shortcomings in their home country. We focus on both ADR listings and voluntary accounting disclosures as two important policy choices that may allow firms to overcome deficiencies in their home country's protection of outside investors. A 2002 McKinsey survey found that $71 \%$ of emerging market investors identified “Accounting Disclosure" as "Very Important" for their investment decision. ${ }^{7}$ These disclosures have also been shown in previous literature to be a primary source of information for foreign investors (see, for example, Bradshaw, Bushee and Miller, 2002).

We create an accounting quality index based on a firm's use of (a) internationallyrecognized accounting standards, (b) quality of the auditor, (c) use of consolidated financial reports, and (d) audit opinion. In addition, we examine both listed and unlisted ADRs issued by emerging market firms. Our results show that, over and above other firm-level factors, ADR issuance and higher quality accounting disclosures lead to greater U.S. mutual fund investment. More importantly, we find that the impact of ADRs and high quality accounting policies is more pronounced in countries with weak shareholder protection.

Our findings on allocations by U.S. mutual funds in emerging markets extend the growing literature on the determinants of global investment flows and allocations. Recent research has examined macroeconomic, political and legal determinants of portfolio investment

\footnotetext{
${ }^{7}$ McKinsey Global Investor Opinion Survey on Corporate Governance 2002. Following "Accounting Disclosure" in importance to investors is "Shareholder Equality" and "Property Rights", which are identified as "Very Important" by $47 \%$ and $46 \%$ of investors, respectively.
} 
inflows at the country-level, but very little research has examined firm-level determinants. A few studies have examined firm-level allocations, but they generally focus on single countries with uniformly high investor protection laws and accounting standards. For example, Falkenstein (1996) investigates the allocations of U.S. open-end mutual funds in U.S. stocks; Kang and Stulz (1994) examine foreign investment in Japan; and Dahlquist and Robertsson (2001) investigate foreign investment in the Swedish market.

Our results add to the growing literature on foreign investment decisions. The theoretical model of Brennan and Cao (1997) uses information asymmetries to motivate differences between domestic and foreign investors. Their empirical analysis shows that domestic investors have informational advantages. Covrig, Lau and $\mathrm{Ng}$ (2002) also conclude that foreign fund managers have less information about domestic stocks than do domestic fund managers. Dahlquist et al. (2002) conclude that the difficulties and cost of gathering information on foreign firms creates a "home bias" and empirically show that a significant proportion of shares are closely held in several countries, hence reducing the float. Our results complement these studies and show an important role for country- and firm-level governance policies in overcoming these information asymmetries.

The rest of the paper is organized as follows. Section I discusses the data used in the empirical analysis. A description of fund characteristics is presented in Section II. The empirical results on the relationship between fund holdings and country characteristics are reported in Section III. Section IV reports results on fund holdings and firm characteristics after controlling for country attributes. A summary and conclusions are provided in Section V. 


\section{Data and Methodology}

\section{A. Mutual Funds Sample}

We obtain portfolio holdings from the February 2002 release of the Morningstar database for each U.S. mutual fund with a stated objective of investing primarily in emerging market equities. ${ }^{8}$ Our analysis focuses on active portfolio allocation decisions of U.S. mutual funds and, therefore, we exclude exchange-traded funds and funds that explicitly follow passive indexing strategies. Consistent with the MSCI Emerging Markets Free Index, we define the following countries as emerging markets: Argentina, Brazil, Chile, China, Colombia, Czech Republic, Egypt, Greece, Hungary, India, Israel, Jordan, Malaysia, Mexico, Morocco, Pakistan, Peru, Philippines, Poland, Russia, South Africa, South Korea, Sri Lanka, Taiwan, Thailand, Turkey and Venezuela.

At the fund level, we collect detailed information on each fund's portfolio holdings, i.e., the proportion of the fund's assets invested in individual firms, the percentage invested in stocks, bonds and cash, investments by region, and investments by industry sectors.

The U.S. mutual funds examined are classified as: Diversified Emerging Markets, Pacific/Asia excluding Japan and Latin America. We exclude Diversified Pacific/Asia mutual funds because the majority of their investments are in countries that are not considered emerging markets, such as, Japan, Hong Kong and Singapore. Similarly, we exclude European funds because of their emphasis on developed Western European markets. In the Pacific/Asia excluding Japan sample of funds, we exclude 11 funds that invest 90 percent or more of their assets in three or less countries. Finally, we also exclude multiple classes of the same emerging market mutual fund. Certain funds have multiple classes that have identical portfolio holdings

\footnotetext{
${ }^{8}$ Because different funds report their portfolio holdings at different times, the February 2002 version of the Morningstar database contains funds' portfolio holdings for October 2001, December 2001, or January 2002.
} 
but different fee structures. For example, one fund may have an exit fee but the other does not. All of the sample funds are primarily equity funds with more than 90 percent of their investment in equities. The final sample consists of 74 Diversified Emerging funds, 25 Pacific/Asia excluding Japan funds and 15 Latin America funds.

\section{B. Country Characteristics}

Our first objective is to determine the impact of country-level characteristics and policies on U.S. mutual fund investment allocations. The first set of characteristics examined is exogenous macroeconomic factors that affect both country-level and firm-level investment allocations by U.S. mutual funds. We include controls for the following macroeconomic variables: $\log$ GDP per capita (LGDPPC), growth in GDP per capita (GDPPCG) and the size of the stock market measured as market capitalization/GDP (MKTCAPGDP. Data for the year 2000 on LGDPPC, GDPPCG and MKTCAPGDP is collected from the IMF's International Finance Statistics (IFS) database. Also included are country-level five-year stock market returns (MKTRETURN) and market turnover (TURNOVER) from Datastream. Market return is expected to capture performance and turnover is a measure of liquidity in the country's stock market.

We then turn to country-level policy choices that are arguably under the control of governments or regulatory agencies. Two major monetary and tax policies we examine are the exchange rate regime and the withholding rate on investment returns. We use an indicator (1-5) of whether the exchange rate regime is a float, managed float, or pegged (EXRATE) and the withholding tax rate on dividends (WTAX). WTAX is from the S\&P Emerging Markets Factbook and the exchange rate classification used is according to Reinhart and Rogoff (2003). ${ }^{9}$

\footnotetext{
${ }^{9}$ The witholding tax rate on dividends, WTAX, is missing for many countries in our sample and therefore is only included for robustness.
} 
Next, we focus on country-level policies that protect the claims of outside investors. Denis and McConnell (2002) define corporate governance as the set of mechanisms designed to induce managers to make decisions that maximize shareholders' wealth. For example, good corporate governance deters managers from expropriating shareholder wealth and therefore shareholders have more confidence investing in a company. La Porta et al. (1997, 1998, 2000a) discuss the role of strong investor protection laws and enforcement in fostering corporate governance that protects and attracts outside investors. Their empirical results show that better investor protection laws, law enforcement institutions, and average accounting quality are associated with more developed capital markets. The quality of information provided to outside investors is also higher in countries with strong investor protection (see, for example, Leuz, Nanda, and Wysocki, 2003). We directly test the impact of these country-level policies on U.S. mutual fund investment allocations. If good country-level policies protect the claims of outside investors, then we should find that foreign institutions invest more in countries with policies that are favorable to them.

To investigate the impact of country-level investor protection policies on foreign investment, we use three measures of corporate governance: Shareholder rights (SHRIGHTS), legality (LEGALITY) and average firm-level accounting disclosures (ACCOUNT) as indicators of shareholder protection, efficiency of the legal framework, and the average quality of financial reporting to outside investors, respectively. The SHRIGHTS measure is the "anti-director rights" index developed by La Porta et al. (1998) and updated to include emerging markets by Pistor (2000). The index is constructed to capture the rights of minority shareholders and is the sum of dummies identifying one-share/one vote, proxy by mail, unblocked shares, cumulative vote/proportional representation, preemptive rights, oppressed minority, and $\%$ of shares needed 
to call a shareholders' meeting. LEGALITY is an index of the strength of the legal system and institutional environment constructed as a weighted average of judicial efficiency, rule of law, corruption, risk of expropriation and risk of contract repudiation using principal component analysis (Berkowitz, Pistor, and Richard, 2002).

To investigate the impact of firms' accounting disclosure choices on U.S. mutual fund allocations, we use a country-level variable reported by La Porta et al., 1998. This variable (ACCOUNT) captures the average quality of firms' accounting disclosures within each country. It measures the inclusion or omission of 90 items reported by firms in their annual financial reports. Therefore, it can be viewed as capturing both the average of individual firm's discretionary disclosure policy choices and the effect of country-level mandated accounting standards.

\section{Firm-Specific Attributes}

We next extend our analysis to the firm-level. Previous literature has shown a relationship between better firm-level governance and higher financial and equity performance in developed and emerging markets (for example, Gompers, Ishi and Metrick (2001), Klapper and Love (2003) and Black, Jang and Kim (2003), respectively). Prior studies have also shown that foreign investors are more likely to invest in firms that have high visibility. For example, Lang, Lins and Miller (2002a) find that firms with ADRs have better information environments that are then associated with higher market valuations. Edison and Warnock (2003) investigate the aggregate holdings of U.S. investors in large emerging markets and find that holdings are weighted more towards large stocks, particularly those listed in the U.S.

We first examine firm characteristics that, while being arguably exogenous, are likely to affect mutual funds' investment allocations. These variables are obtained from the Worldscope 
and $\mathrm{I} / \mathrm{B} / \mathrm{E} / \mathrm{S}$ databases and include firm size as measured by log of total assets in U.S. dollars (LASSETS), the number of analysts following the firm as reported by I/B/E/S (NANALYSTS), the total stock return for a 12-month period (TRETURN), dividend yield (DYIELD), leverage, defined as total debt/ total capital (TDTCAP) and performance, measured alternatively as return on equity (ROE) and price to book ratio (PB) ${ }^{10}$ We also calculate float (FLOAT) from the Worldscope data and obtain firm-level turnover (FTURNOVER) from the Emerging Market Database. However, a large number of observations are missing for these two variables and therefore results are reported excluding them. Lang, Lins and Miller (2002b) conclude that analyst following matters most when investors are protected least. Therefore, analysts appear to play an important role in information gathering and monitoring management's actions. While analyst following may indirectly capture the quality of a firm's discretionary governance choices, we view it as exogenous from the perspective of the firm.

Finally, we examine firm-level discretionary policies that can directly affect foreign investment allocations. Firms can decide to adopt U.S. governance and disclosure rules by issuing an American Depository Receipt (ADR). We use ADR listings as reported by the Bank of New York website. The ADR dummy is equal to one if the firm has an ADR, and zero otherwise. In some specifications we distinguish between ADRs listed on NYSE, AMEX and NASDAQ versus unlisted ADRs trading on OTC or as 144As, because listed ADRs have higher disclosure and float requirements (i.e. U.S. GAAP, etc.).

\footnotetext{
${ }^{10}$ Total market capitalization is an alternate measure of firm size. However, the total market capitalization is likely to be endogenous to other factors including U.S. mutual fund investment. Therefore, our main analysis focuses on a balance sheet measure of firm size. However, the results are robust to the use of market capitalization or firm sales as alternate measures of firm size.
} 
As an alternative to ADR issuance, emerging market firms can also voluntarily adopt higher quality disclosures. To capture these choices, we include four accounting and disclosure quality variables: auditor quality, consolidated reporting, auditor opinion and use of internationally-recognized accounting standards. First, auditor quality, AUDITOR, is a categorical variable that equals one if the firm uses an international Big-5 accounting firm, and zero otherwise. Although recent accounting scandals have raised doubts regarding the integrity of the large, international accounting firms, prior research has shown that audit quality tends to be higher for Big-5 auditors. Second, we create a consolidation variable, CONSOL, which equals one if the firm presents consolidated financial statements, and zero otherwise. Consolidated financial reports are expected to present a more complete performance picture of all of a firm's investments and subsidiaries. Consolidated statements are particularly important in emerging markets where family groups and pyramid ownership schemes are prevalent. Third, we create a clean audit opinion variable, OPINION, which equals one if the firm receives a clean opinion from its auditor, and zero otherwise. Finally, ACCSTD is a categorical variable that equals one for firms that use internationally recognized accounting standards (U.S. GAAP or International Accounting Standards), and zero otherwise. Firms that use internationally recognized accounting standards are viewed as having financial statements that present a "true and fair" picture of firm performance. The relationship between adoption of U.S. GAAP and institutional investment is examined by Bradshaw, Bushee and Miller (2002). They find that firms with greater degree of conformity with U.S. GAAP exhibit greater levels of institutional ownership.

We create an index ACQUALITY equal to the sum of the four separate accounting quality variables. The value of ACQUALITY ranges from 0 to 4 , with 0 being the weakest and 4 
being the strongest accounting quality at the firm-level. We use the index ACQUALITY in our analysis instead of each of the four separate variables.

\section{MSCI Index Benchmark}

We use the MSCI Emerging Markets Free Index as the market benchmark. This is a free float-adjusted market capitalization weighted index designed to measure equity market performance in global emerging markets. The index reflects investable opportunities for global investors by taking into account restrictions on foreign ownership. The market capitalization of a firm is first adjusted for free-float and is further modified by foreign ownership limits that might have been placed by the firm. The more restrictive of the two limitations is applied. Bailey, Chung, and Kang (1999) and Bailey and Jagtiani (1994) discuss the impact of ownership restrictions on stock prices. According to a survey conducted by Pensions \& Investments, over $90 \%$ of international institutional equity assets in the U.S. are benchmarked to MSCI Indices. ${ }^{11}$ Our objective is to examine the fund managers' allocation decisions. These managers oversee actively managed funds and therefore their portfolio holdings are expected to differ from a benchmark index. However, fund managers are compensated based on their performance relative to a benchmark and therefore it is important to also do the analysis relative to the MSCI index.

The weight of each security in the global MSCI index is obtained from Morgan Stanley Capital International. These global weights also allow us to build separate indices at the regional and country-levels. For example, in order to construct the Latin American Index we include only Latin American firms that are included in the broad MSCI Emerging Markets Free Index and to construct the Asian index we include only the Asian firms. There were 649 firms in the MSCI Emerging Markets Free Index after excluding multiple classes of securities for which data is

\footnotetext{
${ }^{11}$ This information is from MSCI's website www.msci.com.
} 
available in Worldscope. Multiple classes of securities of the same firm are combined to derive one weight for each firm. We examine the characteristics of (a) firms that are included in the MSCI Index and are also included in the mutual funds' portfolio holdings, (b) firms that are included in the MSCI Index, but are not included in mutual fund portfolio holdings, and (c) firms that are not included in the MSCI index, but are included in the mutual fund portfolio holdings.

\section{E. Methodology \\ E.1 Country-Level}

We first conduct our analysis at the country-level. Several regression models are estimated to study the relationship between fund allocation and country characteristics. ${ }^{12} \mathrm{We}$ include all categories of funds in the regressions, with dummies identifying fund types: Diversified Emerging, Asia and Latin America (excluded). In the first model, we only include macroeconomic factors such as the size of the economy, measured by log of GDP per capita (LGDPPC), an indicator of the exchange rate regime (EXRATE), and an indicator of equity market development measured by market capitalization to GDP (MKTCAPGDP). ${ }^{13}$ The second regression also includes five-year market returns and liquidity, MKTRETURN and TURNOVER, respectively.

The third model includes all macroeconomic and market factors, plus the indicator of shareholder rights (SHRIGHTS), the measure of average firm-level accounting quality (ACCOUNT), plus the interaction term (SHRIGHTS*ACCOUNT). This interaction term allows us to determine if, on average, firms' individual accounting policy choices have a more

\footnotetext{
${ }^{12}$ Although we estimate firm ownership, it is not used as the dependent variable because our objective is to model the fund manager's decision-making process. The fund manager must decide what proportion of a fund's assets to allocate to the firm. In addition, Bradshaw, Bushee, and Miller (2002) find that it is the increase in U.S. GAAP conformity that leads to institutional investment and not vice versa.

${ }^{13}$ For robustness, we ran a specification that included growth in GDP per capita (GDPPCG). However, this variable is significantly correlated with LGDPPC and therefore we report results with only LGDPPC.
} 
pronounced effect on U.S. mutual fund investment allocations in the presence of weak countrylevel investor protection policies. The final model is similar to the prior specification, but substitutes the country-level LEGALITY variable for the SHRIGHTS variable.

The model is expressed as follows:

$$
\begin{aligned}
\% \text { Fund Allocation }= & \alpha_{0}+\beta_{1}(\text { macro variables })+\gamma(\text { SHRIGHTS })+\delta(\text { ACCOUNT })+ \\
& \phi\left(\text { SHRIGHTS }^{*} \text { ACCOUNT }\right)
\end{aligned}
$$

In order to study the under and over weighting of funds' investment allocations relative to the MSCI benchmark, we repeat the above analysis using the "\% Relative Spread" as the dependent variable and is defined as:

$$
\% \text { Relative Spread }=(\% \text { Fund Allocation - \% MSCI Weight })
$$

This spread measure captures discretionary investment allocations to countries and firms that deviate from a passive indexing strategy.

\section{E.2 Firm-Level}

At the firm-level, we first estimate a simple logit model to examine the characteristics of firms that are included in fund holdings relative to the overall population of firms. We assume that the emerging market firms included in Worldscope constitute the population of investable firms. ${ }^{14}$ The dependent variable (DFund) equals one if the firm is included in any fund's portfolio holdings, and zero otherwise:

$$
\text { DFund } \left.=\alpha+\beta_{1} \text { (macro variables }\right)+\beta_{2}(\text { firm variables })+\gamma(\text { SHRIGHTS }+\phi(\text { ACQUALITY }) \text { (3) }
$$

We include the basic macroeconomic and market variables included in the country-level regressions. Firm-level explanatory variables include TDTCAP, TRETURN, DYIELD,

\footnotetext{
${ }^{14}$ We do recognize that Worldscope coverage is biased towards larger, more liquid firms that are of the greatest interest to investors. For this reason, our coverage of less developed equity markets is limited.
} 
LASSETS, ROE and PB. In addition, we include a number of indicators of firm-level corporate governance: the log of market capitalization in U.S. dollars (LMVALUEUSD), since size may be a proxy for better media coverage and transparency, number of analysts (NANALYSTS), which may also indicate greater transparency, ADR dummy (ADR), which indicates greater disclosure and governance requirements, and ACQUALITY, which is our index of accounting quality.

After examining the characteristics of firms included in the funds' portfolio relative to the population of firms, we next examine mean allocations by the fund to each firm. If a firm is not included in the funds' portfolio then its allocation is zero. Next, we conduct a firm-level regression analysis that is similar to the country-level regression model in equation (1). Again, several regression specifications are estimated. The final model includes country characteristics and policies, firm characteristics and policies, and the interaction of country and firm governance policies as shown below. The two firm-level discretionary governance variables included are ACQUALITY and ADR dummy.

$\%$ Fund Allocation $=\alpha+\beta($ macro variables $)+\gamma($ firm variables.$)+\delta($ SHRIGHTS $)+$

$$
\phi(A C Q U A L I T Y)+(\text { SHRIGHTS*ACQUALITY })
$$

We include an interaction term to test the effect of firm-level accounting quality relative to country-level investor protection. ACQUALITY is replaced by ADR dummy in one of the specifications similar to equation (4). Klapper and Love (2001) find that firm-level corporate governance is more important in countries that have weaker investor protection. Similarly, Doidge, Karolyi and Stulz (2001) conclude that controlling shareholders give up more of their benefits of control in countries with low investor protection. We expect that firm-level governance and accounting quality will matter more to foreign institutional investors in countries with weaker country-level shareholder protection laws. 
We also estimate equation 4 using \% Relative Spread as the dependent variable at the firm-level in order to examine the characteristics of firms in which investment is under or over weighted relative to the MSCI index.

\section{Fund Characteristics and Allocations}

Table 1 shows summary statistics of mutual fund characteristics, by fund type. We include three different types of funds that invest in emerging markets. The first category is Diversified Emerging market funds that invest primarily in emerging markets around the world and generally do not concentrate their investments in any one region. The second is Latin American funds that have at least $75 \%$ of assets are invested in the region. The third category is Pacific/Asia excluding Japan funds that invest at least $75 \%$ of their assets in Pacific countries, with less than $10 \%$ of stocks invested in Japan. We refer to the last category as Asian funds.

As shown in Table 1, the Diversified Emerging Market funds are on average much larger in size than any of the other fund categories, with mean net assets of $\$ 139.42$ million under management. Latin America funds are the smallest with mean assets of $\$ 33.81$ million under management. On average, funds hold positions in 80 firms. The Diversified Emerging category is the most diversified and also the largest in terms of assets under management and these funds have 108 holdings on average. Latin American funds on average hold 38 positions, and Asian funds (Pacific/Asia excluding Japan) hold 31. The actual number of positions taken by funds is larger than those reported here because a fund may hold several different classes of the same firm's equity.

Mean asset turnover is close to 100 percent on average and Diversified Emerging has the highest turnover at 104 percent. The sensitivity of the fund portfolios relative to the U.S. market is captured by beta. The three fund categories have much higher volatility than the Standard and 
Poor's 500 Index as measured by betas of 1.21-1.39. The Latin America category has the highest beta at 1.39 . These are all equity funds therefore on average $94-95$ percent of their assets are invested in equities and only small amounts are invested in bonds or held as cash. The portfolio holdings of the funds are concentrated as captured by the proportion of a fund's portfolio invested in top-ten holdings. The concentration is lowest for Diversified funds with 28 percent invested in top-ten holdings and is highest for Latin American funds that have 54 percent of their assets invested in top-ten holdings. ${ }^{15}$

\section{Fund Allocations and Country Analysis}

\section{A. Fund Allocations at Country-Level}

The first part of our empirical analysis examines fund investments at the country-level and then analyzes fund investments in a country relative to the weight of the country in the MSCI Index. As discussed earlier, the MSCI Index is constructed at three levels: 1) Asia, 2) Latin America, and 3) Diversified Emerging in order to make the appropriate comparisons with the three fund categories included in our study. Asian funds invest in nine countries: China, Indonesia, India, Korea, Malaysia, Philippines, Sri Lanka, Taiwan and Thailand. Of the 25 funds, 24 have investments in Korea and Taiwan as seen in Table 2. Only one fund invests in Sri Lanka. The MSCI Index includes firms from all the nine countries except Sri Lanka. The MSCI Index includes firms in Pakistan, although no fund has an investment in Pakistan. The MSCI index includes the largest number of firms in Taiwan (88 firms), Korea (76 firms), Malaysia (66 firms) and India (58 firms).

\footnotetext{
${ }^{15}$ U.S. law prevents mutual funds from owning more than $5 \%$ of any company's total stock. In addition, some countries may restrict ownership of financial institutions and media companies. However, all countries in our sample allow some foreign ownership in all firms. In addition, in our sample the allocation of any fund into any particular stock does not exceed $5 \%$ of the firm's total equity.
} 
All 15 Latin American funds invest in Brazil and Mexico. Only one fund invests in Venezuela. The MSCI Index for Latin America includes 34 firms from Brazil, 22 from Chile and Mexico, and only 5 firms from Venezuela. All 74 U.S. Diversified Emerging mutual funds invest in Korea and Mexico. Other countries frequently included in fund portfolios are India (71 funds), Taiwan (71 funds), Thailand (69 funds), Israel (68 funds) and South Africa (68 funds). The countries with the smallest number of funds are Jordan (1 fund), Slovenia (2 funds), Zimbabwe (3 funds), Ghana (3 funds), Venezuela (3 funds) and Morocco (4 funds). ${ }^{16}$

Table 3 reports the average proportion of fund's assets invested in each country, by fund type. Also reported are the weights of the countries in the MSCI Index. The countries with the largest weights in the portfolio of Asian funds are Korea (40.78\%) and Taiwan (27.77\%). These two countries also have the largest weights in the MSCI Asia Index with Korea at $31.73 \%$ and Taiwan at $28.04 \%$. Next, we analyze the proportion of a fund's assets invested in a country relative to the country's weight in the MSCI Index. Therefore, relative to the Asian Index the funds over-invest in Korea by $9.05 \%$ and under-invest in Taiwan by $0.27 \%$ as measured by $\%$ Relative Spread. Fund portfolios under-weight firms in China, Indonesia, India, Malaysia, Philippines and Taiwan relative to the MSCI weights.

Latin American funds, on average, invest $47.78 \%$ and $40.98 \%$ of their assets in Mexico and Brazil, respectively. Mexican firms constitute $40.14 \%$ of the MSCI Latin America Index and Brazilian firms constitute $40.14 \%$. Therefore, Mexico is over-weighted by $7.64 \%$ in fund portfolios and Brazil is over-weighted by $0.54 \%$. Fund portfolios under-weight firms in Argentina, Chile, Colombia, Peru and Venezuela relative to the Index.

\footnotetext{
${ }^{16}$ The following countries are not included in Tables 2 and 3 for lack of space: Jordan, Slovenia, Zimbabwe, and Ghana.
} 
Diversified Emerging funds invest in a total of 30 countries and, on average, invest a smaller proportion of their assets in firms from a single country as compared to the regional Asian and Latin American funds. On average, Korean firms receive the largest proportion of the funds' assets (18.86\%), followed by Mexico (13.50\%), Taiwan (11.17\%) and Brazil (10.17\%). These same countries also have the largest weights in the MSCI Index. However, there is considerable variation in the funds' over/under-investment investments relative to the Index.

\section{B. Fund Allocations and Country-Level Attributes}

We next relate the funds' portfolio holdings to country attributes. The objective is to examine the country-level factors that may influence a fund's portfolio holdings in a country. Fund portfolio holdings are measured in two ways: 1) the percentage of funds' absolute allocation to each country; and 2) the "\% Relative Spread" that measures the over and underinvestment of funds by calculating the difference between the firms' allocated weight and the MSCI Index weight for each country. These two variables are used as our dependant variables.

We first report correlations for attributes at the country-level in Table 4. Log of GDP per capita is included in all regression models to control for size of the country's economy. This variable is not significantly correlated with any of the other variables used in the regression models except EXRATE, LEGALITY and ACCOUNT. LGDPPC is positively related with market capitalization to GDP with a correlation of 0.27 but is not significant. MKTCAPGDP is significantly and positively correlated with accounting standards in the country $(0.60)$ and also with LEGALITY (0.52). Because of the high correlations, separate regression models are estimated.

Table 5 presents regression results using the \% Fund Allocation as the dependant variable. The models are estimated including all fund categories - Asian, Latin American and Diversified Emerging - and fund type dummies (DASIA and DDIV, excluding DLATIN). The 
number of observations is equal to the number of funds in each category times the number of countries, summed across fund types. The sample is uneven across regressions because our country-level governance variables are not available for some countries.

The first column in Table 5 shows only the macroeconomic variables and suggests that funds invest more in countries with more developed economies, as measured by log of GDP per capita (LGDPPC), floating exchange rate regimes, as captured by EXRATE, and relatively larger stock markets as measured by the ratio of market capitalization to GDP (MKTCAPGDP). We find all three variables to be positive and significant in the first specification as shown in column 1. These results highlight the need for stable macroeconomic policies in order to develop financial markets. A variable measuring the withholding tax on dividends is also significant in this restricted model, suggesting the importance of investor-friendly tax regimes (not shown). Column 2 controls for market characteristics and finds that greater return and liquidity increases foreign investment. Not surprisingly, investors prefer to invest in more active markets with lower expected transaction costs.

Columns 3 and 4 control for macroeconomic and market development and include our proxies for corporate governance, SHRIGHTS and LEGALITY, and country-level average accounting quality, ACCOUNT. ${ }^{17}$ We find that SHRIGHTS, LEGALITY and ACCOUNT are positively and significantly related to foreign investment, after controlling for other county-level attributes. In addition, the interactions of both sets of variables (SHRIGHTS*ACCOUNT and LEGALITY*ACCOUNT) are negative and significant. We show this as evidence to the importance of a strong legal framework and accounting standards to attract foreign investment. Furthermore, we interpret the interaction term to suggest that good accounting practices

\footnotetext{
${ }^{17}$ For example, DeFond and Hung (2003) find investor protection to be related to law enforcement but not to an extensive set of laws.
} 
(ACCOUNT) matter more in countries with weak laws and judicial enforcement (as proxied by SHRIGHTS and LEGALITY, respectively). In particular, greater transparency and disclosure is even more important in countries where minority shareholders have ex-ante weaker power and voice in firm decisions and investors believe the courts are slow and inefficient in the case of expost distress. ${ }^{18}$

Next, we examine in Table 6 the relationship between \% Relative Spread and country characteristics. Our indicator of exchange rate regime, EXRATE is robust in three of the four specifications, confirming the importance of exchange rate policy to foreign investors. Funds invest more of their assets relative to the MSCI Index weights in countries with less developed equity markets as measured by market capitalization to GDP, suggesting that firms overinvest in countries that are less represented in the MSCI index (rather than additional firms in countries with more developed markets that are already heavily represented). Columns 3 and 4 investigate further which countries funds choose to overinvest in. Similar to our findings in Table 5, we find in Column 3 that county-level shareholder rights (SHRIGHTS) and average accounting standards (ACCOUNT) are significantly important and that better accounting practices matter more in countries with weak investor protection. However, our results are not robust to the substitution of LEGALITY as our measure of country-level governance. This suggests that accounting standards and investor protection are more important to foreign institutional investors. It might be the case that the strategy of foreign investors is to avoid using local courts - and requiring local judicial efficiency - by performing comprehensive due diligence (that requires good accounting disclosure and transparency) and executing their rights prior to distress (i.e. the right

\footnotetext{
${ }^{18}$ It may also be the case that in countries with weak accounting standards, investors value more the ability to exante write stronger contracts and ex-post enforce the contracts in a court of law.
} 
to vote by proxy, etc.) These results must be interpreted cautiously because LEGALITY is significant correlated with many of the other variables included in the specification. We explore further the importance of firm-level accounting standards in the next section.

\section{Fund Allocations and Firm Analysis}

\section{A. Fund Portfolios}

We examine the characteristics of emerging market firms included in the portfolio holdings of U.S. mutual funds and compare them to all firms in the Worldscope database. Worldscope covers a total of 4,138 firms for the emerging markets in our sample. We assume this is the population of publicly traded firms in emerging markets available to U.S. mutual funds to make investment allocations. Table 7 shows the median values for firm characteristics classified in three groups. Group 1 consists of all 4,138 Worldscope firms; Group 2 consists of 2,831 firms that are in Worldscope but are not included in the mutual fund portfolio holdings; and Group 3 consists of 1,307 firms that are in Worldscope and in the mutual funds portfolio holdings.

A comparison of the three columns shows that U.S. mutual funds invest in firms that are on average (median) larger as measured by market capitalization and have higher leverage as measured by total debt to total capital. They also invest in firms that have higher profitability as measured by ROE, ROA and PB, and also have higher dividend yield relative to the average firm in Worldscope. Fund firms also have a higher float. Float for emerging market firms is low and has a median value of $45.73 \%$. This implies that more than half the shares are closely held. This reduces liquidity in secondary market trading for these firms and institutions do not like to invest in firms with low liquidity. Our findings are similar to those of Dahlquist and Robertson (2001) for Sweden, Kang and Stulz (1997) for Japan, and Falkenstein (1996) for the United States. 
Dahlquist et al (2002) conclude that home bias is linked to corporate governance. They report that in countries where investors are poorly protected it is optimal for firms to be closely held. Therefore, it is not surprising to find low float for emerging market firms. There is a large difference in the number of analysts following a firm between the groups. On average, four analysts follow firms that are in fund portfolios compared to only one for all firms in Worldscope. The median accounting quality is the same at two for each of the three categories.

Table 8 presents correlation coefficients for firm-level attributes. The correlation between market value and number of analysts; between market value and accounting standards; and between number of analysts and accounting standards is positive and significant at the $5 \%$ significance level. The ADR dummy has a positive and significant correlation with firm size, number of analysts, and accounting quality. Therefore, in our multivariate framework we are careful not to include all of these attributes as explanatory variables in the same model.

Next, we estimate a logit model to analyze differences between firms from Worldscope that are included in the portfolio holdings and those firms that are not included in the portfolio. In our models the dependent variable (DFUND) equals one if a Worldscope firm is included in the funds' portfolio holding, and zero otherwise. Country-level macroeconomic variables and industry dummies indicating 1-digit SIC industrial codes are included in all models. Corporate governance variables at the country-level are not included here but are the focus of analysis in the next section. In addition to a baseline model, we also estimate different models that separately include analyst following, ADR listing or accounting standards as determinants of U.S. mutual fund investment. These models are estimated separately because of the high correlation between the three variables. We do not report results that include float and firm-level turnover because a number of observations are lost due to missing data on these two variables. 
Three main conclusions can be reached from the logit regression results reported in Table 9. First, size and visibility of the firm as proxied by firm size, number of analysts following the firm, and ADR dummy are significant and positively associated with U.S. mutual fund investments. Second, an ADR listing is significant, whether or not the firm lists in the U.S. on an exchange (ADRLIST) or trades over-the-counter (ADRUNLIST), although the coefficient is almost twice as large for listed ADRs. This suggests that the greater visibility and lower trading costs associated with even a non-listed U.S. listing may encourage foreign investment, although the impact is larger for firms listed on an exchange that also have mandatory disclosure requirements. Third, firms with better quality accounting quality (ACQUALITY) are associated with allocations from U.S. mutual funds. ${ }^{19}$ These results lead us to conclude that size and visibility of the firm and firm-level accounting quality are important attributes that are associated with investments by U.S. mutual funds. However, the reduced form model estimated in this section does not allow us to fully capture the details of the allocation decision. Therefore, the next section examines firm and country attributes that are related to the level of fund allocations in a regression framework.

\section{B. Fund Allocation and Firm-Level Attributes}

We estimate several regression models to further analyze the relationship between firm characteristics and funds' investment allocations in a multivariate framework. ${ }^{20}$ In Table 10 , we first investigate the determinants of U.S. funds allocations to emerging market firms measured as the mean proportion of the funds' assets invested in a firm (expressed as a percentage). Each fund's allocation adds up to 100 percent. The variables have been winsorized (to correct for outliers) and robust standard errors are estimated in each case. All regressions include country-

\footnotetext{
${ }^{19}$ We also estimated the regressions with the individual accounting quality variables and the results are similar.

${ }^{20}$ The analysis was repeated by weighting allocation by size of the funds as measured by total market value of the fund's assets. The results are not reported here.
} 
specific variables: the log of GDP per capita (LGDPPC), exchange rate regime (EXRATE) and market capitalization to GDP (MKTCAPGDP). Gillan, Hartzell and Starks (2002) empirically find that an industry's investment opportunities, competitive environment, and information environment plays an important role in its corporate governance structure. Therefore, industry fixed effects are also included, but not reported. Firm-specific independent variables included in all models are dividend yield (DYIELD), total debt to total capital (TDTCAP), 12-month stock return (TRETURN), ROE, price-to-book ratio (PB), and firm size as measured by the logarithm of total assets in U.S. dollars (LASSETS) ${ }^{21}$ Consistent with prior research, we find a key determinant of fund allocation decisions is firm size. For example, a doubling in firm size leads to approximately a $0.12 \%$ increase in the allocation of funds to a firm. The regression specifications also suggest that analyst coverage is an important determinant of fund allocation decisions as shown in column 1 of Table 10 .

We next analyze the relationship between U.S. funds' investment allocations and country-level shareholder rights and firm-level discretionary policies. ${ }^{22}$ Countries have the option to select an appropriate shareholder rights regime that is conducive to foreign investment. Similarly, firms also have the option to issue an ADR and adopt higher disclosure requirements. They can also create transparency and provide more information by adopting better accounting policies. Therefore, we estimate two different specifications that include the interactive effects of shareholder rights, ADR listings and accounting quality. The coefficient on ADR listings suggests that a one rank improvement in accounting quality leads to an average asset allocation increase of $0.71 \%$ and this impact is statistically significant. The coefficients of the interaction

\footnotetext{
${ }^{21}$ We do not report results that include float and firm-level turnover because the sample size is reduced significantly due to missing data.

${ }^{22}$ LEGALITY is not included in the specifications due to concerns about high correlation. The significance of ADR and ACQUALITY increases if some other firm-level variables such as size and analyst coverage are not included in the model. There is high correlation among some of these variables.
} 
terms in the two models (ADR and SHRIGHTS, ACQUALITY and SHRIGHTS) are negative and significant. This leads to the conclusion that the marginal effect of both firm-level policies ADR and accounting quality - is significant in countries with below-average outside shareholder protection laws. In general, we can conclude that funds invest a larger proportion of their assets in firms with more disclosure and transparency and this effect is most pronounced in countries with weak shareholder rights.

\section{Fund Allocations Relative to MSCI Index}

In this section, we analyze U.S. fund managers' active investment allocations to emerging market firms that deviate from passive MSCI benchmarks. These tests allow us to identify firm characteristics and policies that are associated with greater U.S. mutual fund investment allocations relative to the MSCI benchmark.

Table 11 provides a comparison of three groups of firms. Group 1 consists of 782 firms that are included in our funds' portfolio holdings, but are not in the global MSCI Index. ${ }^{23}$ Group 2 consists of 525 firms that are both in the MSCI Index and in our sample of U.S. mutual funds' holdings. Group 3 consists of 124 firms that are in MSCI Index, but are not included in any of the funds' holdings. ${ }^{24}$ There is considerable overlap between firms included in MSCI Index and in portfolio holdings. However, funds invest in a large number of firms that are not part of the index. This is not surprising because these are "actively managed" funds. This highlights that funds are not simply mimicking the MSCI portfolio.

The mean and median market capitalization of firms in the MSCI index is US\$1.25 billion and US\$366 million, respectively. The minimum and maximum values are US\$9 million and US $\$ 40.65$ billion, respectively. The index consists of both some very large and very small firms.

\footnotetext{
${ }^{23}$ Funds may be included in any of the three fund categories for the purpose of this analysis.

2436 firms that are included in the MSCI index are not covered in Worldscope. Frequently these are newer firms that recently had an IPO and therefore coverage in Worldscope has not started.
} 
The mean and median weight of the firms in the index is $0.124 \%$ and $0.04 \%$, respectively. The minimum weight can be quite small and almost equal to zero percent and the largest weight in the index is $4.03 \%$. The three firms with the largest weights in the index are Samsung Electronics, Taiwan Semiconductor and China Mobile.

We first focus on analyzing the differences between characteristics of firms in Group 1 (in funds' portfolios, but not in MSCI Index) and Group 2 (in funds' portfolios and also in MSCI Index. Table 11 shows that firms in the funds' portfolio holdings that overlap with the MSCI index are larger in size, have higher dividend yield, and lower leverage. These firms perform better as measured by ROE. The median number of analysts following firms that are included in both the funds' holdings and in MSCI (Group 2) is 10, much higher than the median analyst following of 2 for firms that are not in MSCI (Group 1). $40 \%$ of the firms that are included in both fund portfolios and the MSCI Index have ADRs (listed or unlisted). Almost half of the ADRs are listed.

Finally, we examine U.S. mutual funds' firm-level investment allocations relative to MSCI benchmarks. The relative fund allocation can be positive, negative, or zero. It will be positive if the fund allocates a larger percentage of its assets to the firm than the market index. This will certainly be the case for the firms that are part of the fund portfolio holdings, but are not included in the MSCI index. Relative fund allocation will be negative if the fund allocates a smaller percentage of its assets to a firm than the index does. Again, this will certainly be the case for firms that are included in the MSCI index, but are not found in U.S. funds' portfolios.

The MSCI benchmark regressions for fund investment allocations are presented in Table 12. Consistent with the regression results in Table 10, we find that U.S. funds significantly overweight their holdings (relative to the MSCI benchmark) to larger firms, firms with higher leverage, and firms with greater analyst following. It should be noted that firm size also captures 
other firm characteristics such as visibility and/or liquidity. Again, the impact of the number of analysts on U.S. mutual fund allocation (relative to the MSCI Index) is consistent with our prior findings. We then turn to the specifications that include firm-level and country-level policies. In this case, ADR listings, shareholder rights and the interaction of these two terms are statistically insignificant. Therefore, funds do not seem to invest larger proportions of their assets in firms that have ADRs relative to the MSCI Index. The firm also has discretion in selecting its accounting policies. We do find ACQUALITY and SHRIGHTS to be both positive and significant and the interaction between them is negative and significant.

These MSCI benchmark regression results suggest that the firm-level accounting quality is an important determinant of fund allocations, even relative to country-level investor protection, and that firm-level accounting quality is more important in countries with weaker shareholder protection. Specifically, the marginal effect of accounting quality is significant in countries with below average shareholder protection laws.

\section{Summary and Conclusions}

This paper examines the relationship between country-level and firm-level characteristics and policies that affect U.S. mutual fund investment allocations in emerging markets. We focus on emerging markets because foreign capital plays an important role in promoting economic growth in countries with developing financial systems. Moreover, emerging markets exhibit wide variation in country-level and firm-level policies that potentially affect foreign investment flows. Our empirical evidence suggests that (a) country-level policies such as floating exchange rates and strong shareholder rights and legal institutions, and (b) firm-level policies such as ADR listing and high quality accounting disclosures are positively associated with U.S. mutual fund 
investment. Moreover, the impact of firm-level policies is most pronounced in countries with weak shareholder rights.

Our mutual fund sample allows us to isolate the role of countries' and firms' "armslength" governance policies on foreign investment decisions. In addition, in contrast to prior related research, we analyze funds' investment allocations that deviate from passive investment strategies that mirror the Morgan Stanley Capital International (MSCI) Emerging Markets Free Index. While there is considerable overlap between the emerging markets holdings of U.S. funds and the MSCI Index, we find that funds do not limit their investments to firms included in a major market index.

At the country-level, our results show that, over and above other measures of macroeconomic development, exchange rate policies, shareholder rights and legal framework are important determinants of U.S. mutual fund investment in emerging markets. Our results also provide insights into the impact of firm-level policies on U.S. funds' investment allocations. We examine both ADR issuance and the adoption of high quality accounting and disclosure choices as possible mechanisms for emerging market firms to attract U.S. mutual fund investment. The voluntary disclosure choices include internationally-recognized accounting standards, auditor quality, auditor opinion and the use of consolidated statements. While results verify that U.S. funds tend to invest in larger growth firms and firms with greater analyst coverage, we also find that funds allocate a larger proportion of their assets to firms with better accounting policies.

Our results suggest that investment by foreign institutions depends not only on the firm's financial attributes but also on transparency and disclosure. We find corporate governance attributes to be important at both the country- and firm-level. However, the two can serve as substitutes. Therefore, steps can be taken at both the country and the firm-level to attract foreign capital and create an environment conducive to foreign institutional investment. Investment by 
foreign institutional investors should lead to higher demand for a firm's stock and therefore lower the firm's cost of capital. Emerging market firms with lower cost of capital will be able to compete effectively in the global market. This should help the economic development of the country.

Our findings on emerging markets extend the growing literature on the determinants of global investment flows and allocations. Prior research focuses on international portfolio flows and examines the relationship between portfolio flows and stock returns. We extend this analysis and undertake a comprehensive analysis of all emerging markets and provide more detailed analysis of country- and firm-level factors that influence investment allocations by U.S. funds. These results are relevant for both policy makers and firms in emerging markets seeking foreign capital to help promote economic and firm growth. 


\section{References}

Allayannis, Yiorgos, Greg Brown, and Leora Klapper, 2003, Capital structure, foreign debt and financial risk: Evidence from East Asia, Journal of Finance, forthcoming.

Bailey, Warren, Y. Peter Chung, and Jun-Koo Kang, 1999, Foreign ownership restrictions and equity price premiums: What drives the demand for cross-border investments? Journal of Financial and Quantitative Analysis 34, 489-512.

Bailey, Warren and Julapa Jagtiani, 1994, Foreign ownership restrictions and stock prices in the Thai capital market, Journal of Financial Economics 36, 57-87.

Berkowitz, Daniel and Katharina Pistor, and Jean-Francois, Richard, 2003, Economic development, legality, and the transplant effect, European Economic Review, 47, 165-195.

Black, Bernard, Hasung Jang, and Woochan Kim, 2003, Does corporate governance affect firm value? Evidence from Korea, working paper, Stanford Law School.

Bradshaw, Mark, Brain Bushee, and Gregory Miller, 2002, Accounting choices, home bias, and US investment in non-US firms, working paper, Harvard Business School.

Borensztein, Eduardo and R. Gaston Gelos, 2001, A panic-prone pack? The behavior of emerging market mutual funds, IMF Staff Papers.

Brennan, Michael and H. Henry Cao, 1997, International portfolio investment flows, Journal of Finance 52, 1851-1880.

Covrig, Lau and Lilian Ng, 2002, Do domestic and foreign fund managers have similar preferences for stock characteristics? A cross-country analysis, working paper, Nanyang Technological University.

Dahlquist, Magnus and Goran Robertsson, 2001, Direct foreign ownership, institutional investors, and firm characteristics, Journal of Financial Economics 59, 413-440.

Dahlquist, Magnus, Lee Pinkowitz, Rene Stulz, and Rohan Willimason, 2002, Corporate governance, investor protection, and the home bias, Journal of Financial Quantitative Analysis, $87-110$.

DeFond, Mark and Mingyo Hung, 2003, Investor protection and corporate governance: Evidence from worldwide CEO turnover, working paper, University of Southern California.

Denis, Diane and John McConnell, 2002, International corporate governance: A survey, working paper, Journal of Financial and Quantitative Analysis 38, 1-36.

Doidge, C., Andrew Karolyi and Rene Stulz, 2001, Why are foreign firms listed in the US worth more? Working paper, NBER. 
Donohue, Jessica Tjornhom and Kenneth Froot, 2002, The persistence of emerging market equity flows, working paper, NBER.

Drogt, Emily L., 2002, Mutual fund investment decisions: the interaction of accounting quality and legal enforcement, working paper, University of Michigan.

Edison, Hali J. and Francis E. Warnock, 2003, U.S. investors' emerging market equity portfolios: A security-level analysis, working paper, International Monetary Fund.

Elton, Edwin and Martin Gruber, 2003, The rationality of asset allocation recommendations, Journal of Financial and Quantitative Analysis 35, 27-41.

Esty, Benjamin, 2003, When do foreign banks finance domestic investment? New evidence on the importance of legal and financial systems, working paper, Harvard Business School.

Falkenstein, Eric G., 1996, Preferences for stock characteristics as revealed by mutual fund portfolio holdings, Journal of Finance 51, 111-135.

Froot, Kenneth, Paul O'Connell and Mark Seasholes, 2001, The portfolio flows of international investors, Journal of Financial Economics, 59, 151-193.

Gelos, R. Gaston and Shang-Jin Wei, 2002, Transparency and international investor behavior, working paper, International Monetary Fund.

Gillan, Stuart L., Jay C. Hartzell and Laura T. Starks, 2002, Industries, investment opportunities, and corporate governance structures, working paper, Center for Corporate Governance, College of Business and Economics, University of Delaware.

Gompers, Paul, Joy Ishi and Andrew Metrick, 2001, Institutional investors and equity prices, Quarterly Journal of Economics, 116, 229-59.

Kaminsky, Graciela L., Richard K. Lyons and Sergio Schmukler, 2001, Mutual fund investment in emerging markets: An overview, World Bank Economic Review 15, 315-340.

Kang, J. K. and Rene Stulz, 1997, Why is there a home-bias? An analysis of foreign portfolio equity ownership in Japan, Journal of Financial Economics, 46, 3-28.

King, Robert and Ross Levine, 1993a, Finance and growth: Schumpeter may be right, Quarterly Journal of Economics, 108, 717-737.

King, Robert and Ross Levine, 1993b, Finance, entrepreneurship, and growth: Theory and evidence," Journal of Monetary Economics, 32, 513-542.

Klapper, Leora and Inessa Love, 2002, Corporate governance, investor protection, and performance in emerging markets, working paper, The World Bank.

La Porta, Rafael, Lopez-de-Silanes, Florencio and Andrei Shleifer, 1997, Legal determinants of external finance, Journal of Finance, 52, 1131-1150. 
La Porta, Rafael, Lopez-de-Silanes, Florencio, Shleifer, Andrei and Robert Vishny, 1998, Law and finance, Journal of Political Economy, 106, 1115-1155.

La Porta, Rafael, Lopez-de-Silanes, Florencio and Andrei Shleifer, 1997, Corporate ownership around the world, Journal of Finance, 54, 471-518.

La Porta, Rafael, Lopez-de-Silanes, Florencio, Shleifer, Andrei and Robert Vishny, 2000, Investor protection and corporate governance, Journal of Financial Economics, 58, 3-27.

Lang, Mark, Karl Lins and Darius Miller, 2002a, ADRs, analysts, and accuracy: Does crosslisting in the U.S. improve a firm's information environment and increase market value? Journal of Accounting Research, forthcoming.

Lang, Mark, Karl Lins and Darius Miller, 2002b, Do analysts matter most when investors are protected least? International evidence, working paper, Indiana University.

Leuz, Christian, Dhananjay Nanda and Peter D. Wysocki, 2003, Investor protection and earnings management: An international comparison. Journal of Financial Economics, 69, forthcoming.

McKinsey Global Investor Opinion Survey on Corporate Governance, 2002, McKinsey \& Company.

Pistor, Katharina, 2000, Patterns of legal change: Shareholder and creditor rights in transition economies, European Business Organization Law Review, 1, 9-108.

Rajan, Raghuram and Luigi Zingales, 1998, Financial dependence and growth, American Economic Review, 88, 559-586.

Reinhart, Carmen and Kenneth S. Rogoff, 2003, The modern history of exchange rate arrangements, working paper, International Monetary Fund.

S\&P Emerging Markets Factbook, 2002, S\&P, New York.

Shleifer, A. and R. Vishny, 1997, A survey of corporate governance, Journal of Finance, 52, 737-783. 
Table 1

\section{Mutual Fund Characteristics}

This table shows summary statistics for the three types of funds examined in the analysis. These include Diversified Emerging Markets funds, Latin America funds and Asia funds (Pacific/Asia excluding Japan). These are the three categories of funds covered by Morningstar that invest primarily in emerging markets' equity. There are a total of 114 funds of which 74 are diversified emerging funds, 15 are Latin American funds, and 25 are Asian funds. The mean fund characteristic information is obtained from the Morningstar February 2002 database. Net Assets is the mean assets under management in millions of US dollars; Fund Holdings is the mean number of holdings in the fund's portfolio; Fund Turnover is the mean percentage of the fund's portfolio holdings that have changed over the past year; Fund Beta is calculated by Morningstar using the Standard and Poor's 500 as the proxy for market return; $\%$ Assets Invested in Equity is the mean percentage of the fund's assets invested in equity; and \% Invested in Top Ten is the mean percentage of the fund's assets invested in top-ten holdings.

\begin{tabular}{|c|c|c|c|c|c|c|c|}
\hline $\begin{array}{l}\text { Fund } \\
\text { Type }\end{array}$ & $\begin{array}{l}\text { Number } \\
\text { of Funds }\end{array}$ & $\begin{array}{l}\text { Fund Net } \\
\text { Assets } \\
\text { (\$ million) }\end{array}$ & $\begin{array}{l}\text { Fund } \\
\text { Holdings }\end{array}$ & $\begin{array}{c}\text { Fund } \\
\text { Turnover } \\
(\%)\end{array}$ & $\begin{array}{l}\text { Fund } \\
\text { Beta }\end{array}$ & $\begin{array}{c}\text { \% Assets } \\
\text { Invested in } \\
\text { Equity }\end{array}$ & $\begin{array}{l}\text { \% Invested } \\
\text { in Top Ten }\end{array}$ \\
\hline All Funds & 114 & 109.57 & 80 & 99.58 & 1.24 & 94.01 & 34.40 \\
\hline $\begin{array}{l}\text { Diversified } \\
\text { Emerging }\end{array}$ & 74 & 139.42 & 108 & 103.90 & 1.21 & 93.53 & 28.00 \\
\hline Latin America & 15 & 33.81 & 38 & 96.79 & 1.39 & 94.37 & 54.13 \\
\hline Asia & 25 & 66.65 & 31 & 89.60 & 1.25 & 95.20 & 41.51 \\
\hline
\end{tabular}


Table 2

\section{MSCI Index Firms and Funds in Countries}

This table shows summary statistics, by fund type. Asian funds can invest in the ten Asian countries listed in the table; Latin American funds can invest in the seven Latin American listed in the table; and Diversified Emerging funds can invest in all emerging markets (in addition to Ghana, Morocco, Jordan and Zimbabwe, not shown). \# Funds in Country is the number of funds investing in a country and \# Firms in Index is the number of firms in the MSCI Index for each country. For example, the first row shows that 22 of the 25 Asian funds in our sample invest in China and that the MSCI index includes 41 Chinese firms.

\begin{tabular}{|c|c|c|c|c|c|c|}
\hline \multirow[b]{2}{*}{ Country } & \multicolumn{2}{|c|}{$\begin{array}{c}\text { Asian Funds } \\
\mathrm{N}=25\end{array}$} & \multicolumn{2}{|c|}{$\begin{array}{c}\text { Latin American Funds } \\
\qquad=15\end{array}$} & \multicolumn{2}{|c|}{$\begin{array}{c}\text { Diversified Funds } \\
N=74\end{array}$} \\
\hline & $\begin{array}{l}\text { \# Funds in } \\
\text { Country }\end{array}$ & $\begin{array}{l}\text { \# Firms in } \\
\text { Index }\end{array}$ & $\begin{array}{l}\text { \# Funds in } \\
\text { Country }\end{array}$ & $\begin{array}{l}\text { \# Firms in } \\
\text { Index }\end{array}$ & $\begin{array}{l}\text { \# Funds in } \\
\text { Country }\end{array}$ & $\begin{array}{l}\text { \# Firms in } \\
\text { Index }\end{array}$ \\
\hline China & 22 & 41 & & & 61 & 41 \\
\hline Indonesia & 9 & 16 & & & 40 & 16 \\
\hline India & 16 & 58 & & & 71 & 58 \\
\hline Korea & 24 & 76 & & & 74 & 76 \\
\hline Malaysia & 19 & 66 & & & 59 & 66 \\
\hline Pakistan & 0 & 9 & & & 6 & 9 \\
\hline Philippines & 7 & 15 & & & 45 & 15 \\
\hline Sri Lanka & 1 & 0 & & & 4 & 0 \\
\hline Taiwan & 24 & 88 & & & 71 & 88 \\
\hline Thailand & 20 & 25 & & & 69 & 25 \\
\hline Argentina & & & 11 & 13 & 30 & 13 \\
\hline Brazil & & & 15 & 34 & 74 & 34 \\
\hline Chile & & & 14 & 22 & 55 & 22 \\
\hline Colombia & & & 3 & 7 & 5 & 7 \\
\hline Mexico & & & 15 & 22 & 74 & 22 \\
\hline Peru & & & 7 & 10 & 28 & 10 \\
\hline Venezuela & & & 1 & 5 & 3 & 5 \\
\hline Czech Rep. & & & & & 42 & 6 \\
\hline Egypt & & & & & 31 & 13 \\
\hline Hungary & & & & & 67 & 7 \\
\hline Israel & & & & & 68 & 32 \\
\hline Morocco & & & & & 4 & 11 \\
\hline Poland & & & & & 58 & 18 \\
\hline Russia & & & & & 65 & 8 \\
\hline South Africa & & & & & 68 & 40 \\
\hline Turkey & & & & & 55 & 30 \\
\hline
\end{tabular}


Table 3

Fund Portfolio Holdings and MSCI Index Weight in Countries

This table shows summary statistics of country allocations, by funds and the MSCI index. Fund's Portfolio is the percentage of assets allocated to a particular country. Index Weight is the country allocation by the MSCI index. \% Relative Spread indicates the fund's over/under investment in a country relative to the MSCI Index:

$\%$ Relative Spread $=(\%$ Fund's Portfolio - \% MSCI Index weight $)$

For example, the first row shows that on average, 9.01\% of Asia Fund assets are invested in China, although the MSCI weight for China is $11.53 \%$ (indicating that on average China is underweighted by $2.52 \%$ ). Ghana, Morocco, Jordan and Zimbabwe, not shown.

\begin{tabular}{|c|c|c|c|c|c|c|c|c|c|}
\hline \multirow[b]{2}{*}{ Country } & \multicolumn{3}{|c|}{ Asia Funds } & \multicolumn{3}{|c|}{ Latin America Funds } & \multicolumn{3}{|c|}{ Diversified Funds } \\
\hline & $\begin{array}{c}\text { Fund's } \\
\text { Portfolio } \\
(\%) \\
\end{array}$ & $\begin{array}{c}\text { Index } \\
\text { Weight } \\
(\%)\end{array}$ & $\begin{array}{c}\text { Relative } \\
\text { Spread } \\
(\%)\end{array}$ & $\begin{array}{c}\text { Fund's } \\
\text { Portfolio } \\
(\%) \\
\end{array}$ & $\begin{array}{c}\text { Index } \\
\text { Weight } \\
(\%) \\
\end{array}$ & $\begin{array}{c}\text { Relative } \\
\text { Spread } \\
(\%)\end{array}$ & $\begin{array}{c}\text { Fund's } \\
\text { Portfolio } \\
(\%) \\
\end{array}$ & $\begin{array}{c}\text { Index } \\
\text { Weight } \\
(\%) \\
\end{array}$ & $\begin{array}{c}\text { Relative } \\
\text { Spread } \\
(\%)\end{array}$ \\
\hline China & 9.01 & 11.53 & -2.52 & & & & 2.39 & 6.23 & -3.84 \\
\hline Indonesia & 1.10 & 1.38 & -0.28 & & & & 1.29 & 0.74 & 0.55 \\
\hline India & 9.43 & 10.83 & -1.40 & & & & 6.78 & 5.85 & 0.93 \\
\hline Korea & 40.78 & 31.73 & 9.05 & & & & 18.86 & 17.14 & 1.72 \\
\hline Malaysia & 6.37 & 12.04 & -5.67 & & & & 3.86 & 6.51 & -2.65 \\
\hline Pakistan & 0 & 0.30 & -0.30 & & & & 0.10 & 0.16 & -0.06 \\
\hline Philippines & 1.04 & 1.28 & -0.24 & & & & 1.57 & 0.69 & 0.88 \\
\hline Sri Lanka & 0.10 & 0 & 0.10 & & & & 0.04 & 0 & 0.04 \\
\hline Taiwan & 27.77 & 28.04 & -0.27 & & & & 11.17 & 15.15 & -3.98 \\
\hline Thailand & 4.40 & 2.87 & 1.53 & & & & 3.29 & 1.55 & 1.74 \\
\hline Argentina & & & & 1.42 & 4.38 & -2.96 & 0.59 & 1.01 & -0.42 \\
\hline Brazil & & & & 40.98 & 40.44 & 0.54 & 10.17 & 9.30 & 0.87 \\
\hline Chile & & & & 8.62 & 11.48 & -2.86 & 1.99 & 2.64 & -0.65 \\
\hline Colombia & & & & 0.07 & 0.62 & -0.55 & 0.05 & 0.14 & -0.09 \\
\hline Mexico & & & & 47.78 & 40.14 & 7.64 & 13.50 & 9.23 & 4.27 \\
\hline Peru & & & & 1.11 & 1.71 & -0.60 & 0.60 & 0.39 & 0.21 \\
\hline Venezuela & & & & 0.03 & 1.23 & -1.20 & 0.02 & 0.28 & -0.26 \\
\hline Czech Rep. & & & & & & & 0.81 & 0.62 & 0.19 \\
\hline Egypt & & & & & & & 0.68 & 0.19 & 0.49 \\
\hline Hungary & & & & & & & 2.56 & 0.94 & 1.62 \\
\hline Israel & & & & & & & 3.20 & 4.33 & -1.13 \\
\hline Poland & & & & & & & 1.60 & 1.14 & 0.46 \\
\hline Russia & & & & & & & 4.35 & 3.37 & 0.98 \\
\hline S. Africa & & & & & & & 8.19 & 10.06 & -1.87 \\
\hline Turkey & & & & & & & 2.24 & 1.88 & 0.36 \\
\hline
\end{tabular}




\section{Table 4}

\section{Correlation between Country Attributes}

This table shows correlations and significance between nine country characteristics. The nine country characteristics are: log of GDP per capita (LGDPPC), growth in GDP per capita (GDPPC), market capitalization to GDP (MKTCAPGDP), average accounting quality of firms (ACCOUNT), shareholder rights (SHRIGHTS), legal framework (LEGALITY), exchange rate regime (EXRATE), five-year market return (MKTRETURN) and market turnover (TURNOVER). Macroeconomic indicators are from the IMF-IFS database; exchange rate regime (EXRATE) is from Reinhart and Rogoff (2003); ACCOUNT and SHRIGHTS ("anti-director rights") are from La Porta et al. (1998) and Pistor (2000); and LEGALITY is an index constructed by Berkowitz, Pistor and Richard (2002) to measure the strength of the legal system. Market characteristics are from Datastream. ${ }^{* *}$ and $*$ indicate significance at the 5 percent and 10 percent level, respectively.

\begin{tabular}{|c|c|c|c|c|c|c|c|c|c|}
\hline & LGDPPC & GDPPCG & МКТCAPGDP & ACCOUNT & SHRIGHTS & LEGALITY & EXRATE & MKTRETURN & TURNOVER \\
\hline$L G D P P C$ & 1.00 & $0.31^{*}$ & 0.27 & $0.42 *$ & -0.04 & $0.76 * *$ & $0.37^{*}$ & 0.29 & -0.03 \\
\hline GDPPCG & & 1.00 & -0.01 & 0.40 & 0.04 & 0.36 & 0.27 & $0.47 * *$ & 0.27 \\
\hline МКТСАРGDP & & & 1.00 & $0.60 * *$ & $0.37 *$ & $0.52 * *$ & 0.02 & -0.15 & -0.09 \\
\hline ACCOUNT & & & & 1.00 & 0.29 & $0.50 * *$ & $0.44 *$ & -0.22 & 0.26 \\
\hline LEGALITY & & & & & & 1.00 & 0.08 & 0.28 & $0.41^{*}$ \\
\hline EXRATE & & & & & & & 1.00 & 0.17 & 0.21 \\
\hline MKTRETURN & & & & & & & & 1.00 & 0.05 \\
\hline TURNOVER & & & & & & & & & 1.00 \\
\hline
\end{tabular}


Table 5

\section{Relationship Between Fund Portfolio Holdings and Country Attributes}

This table shows results of OLS estimations of the determinants of country-level fund allocations. The dependent variable is the cumulative percentage of a fund's assets allocated to firms in the country, by fund. For example, in the case of Asia there are 25 funds and they can invest in any of ten Asian emerging market countries. Therefore, the maximum number of observations for Asian Funds is 25 funds * 10 countries equal to 225 . Many funds have no investment in a country, which means assets allocated to the country are set equal to zero. We include all fund types and dummies DASIA and DDIV indicate Asian and Diversified funds, respectively. The country attributes examined are log of GDP per capita in US dollars (LGDPPC), exchange rate regime (EXRATE), market capitalization to GDP (MKTCAPGDP), market return (MKTRETURN), market turnover (TURNOVER), legal framework (LEGALITY), shareholder rights (SHRIGHTS), and accounting standards (ACCOUNT). Macroeconomic indicators are from the IMF-IFS database. Exchange rate regime (EXRATE) is from Reinhart and Rogoff (2003). ACCOUNT and SHRIGHTS ("anti-director rights") are from La Porta et al. (1998) and Pistor (2000). LEGALITY is an index constructed by Berkowitz, Pistor and Richard (2002) to measure the strength of the legal system. Market characteristics are from Datastream. t-statistics are in parenthesis. ** and * indicate significance at the 5 percent and 10 percent level, respectively.

\begin{tabular}{|c|c|c|c|c|}
\hline INTERCEPT & $\begin{array}{c}-23.12^{* *} \\
(-7.51)\end{array}$ & $\begin{array}{c}-20.71 * * \\
(-6.53)\end{array}$ & $\begin{array}{c}-18.68 * * \\
(-5.11)\end{array}$ & $\begin{array}{c}-37.55^{* *} \\
(-5.24)\end{array}$ \\
\hline LGDPPC & $\begin{array}{l}3.74 * * \\
(13.03)\end{array}$ & $\begin{array}{l}3.48 * * \\
(11.60)\end{array}$ & $\begin{array}{l}1.86^{* *} \\
(3.65)\end{array}$ & $\begin{array}{c}2.83 * * \\
(5.44)\end{array}$ \\
\hline EXRATE & $\begin{array}{l}1.55 * * \\
(13.43)\end{array}$ & $\begin{array}{l}1.24 * * \\
(10.22)\end{array}$ & $\begin{array}{c}0.15 \\
(0.80)\end{array}$ & $\begin{array}{c}0.11 \\
(0.45)\end{array}$ \\
\hline$M K T C A P G D P$ & $\begin{array}{l}0.01 * * \\
(3.91)\end{array}$ & $\begin{array}{l}0.02 * * \\
(6.47)\end{array}$ & $\begin{array}{c}0.00 \\
(0.10)\end{array}$ & $\begin{array}{c}-0.04 * * \\
(-5.91)\end{array}$ \\
\hline MKTRETURN & - & $\begin{array}{l}0.04 * * \\
(6.57)\end{array}$ & $\begin{array}{l}0.04 * * \\
(2.45)\end{array}$ & $\begin{array}{c}0.03 * * \\
(2.39)\end{array}$ \\
\hline TURNOVER & - & $\begin{array}{l}0.01 * * \\
(12.52)\end{array}$ & $\begin{array}{l}0.03 * * \\
(12.01)\end{array}$ & $\begin{array}{c}0.03 * * \\
(9.81)\end{array}$ \\
\hline ACCOUNT & - & - & $\begin{array}{c}0.35^{* *} \\
(5.26)\end{array}$ & $\begin{array}{c}0.46^{* *} \\
(4.50)\end{array}$ \\
\hline SHRIGHTS & - & - & $\begin{array}{l}2.61 * * \\
(2.45)\end{array}$ & - \\
\hline $\begin{array}{l}\text { ACCOUNT* } \\
\text { SHRIGHTS }\end{array}$ & - & - & $\begin{array}{c}-0.07 * * \\
(-2.90)\end{array}$ & - \\
\hline$L E G A L I T Y$ & - & - & - & $\begin{array}{l}1.45 * * \\
(2.78)\end{array}$ \\
\hline $\begin{array}{l}A C C O U N T^{*} \\
L E G A L I T Y\end{array}$ & - & - & - & $\begin{array}{c}-0.02 * * \\
(-2.67)\end{array}$ \\
\hline$D A S I A$ & $\begin{array}{l}-3.76^{* *} \\
(-1.85)\end{array}$ & $\begin{array}{l}-5.28 * * \\
(-2.68)\end{array}$ & $\begin{array}{c}-5.02 * * \\
(-2.41)\end{array}$ & $\begin{array}{c}-4.75^{* *} \\
(-2.28)\end{array}$ \\
\hline$D D I V$ & $\begin{array}{c}-10.94 * * \\
(-5.95)\end{array}$ & $\begin{array}{c}-11.91 * * \\
(-6.56)\end{array}$ & $\begin{array}{c}-11.73 * * \\
(-6.85)\end{array}$ & $\begin{array}{c}-11.53 * * \\
(-6.61)\end{array}$ \\
\hline$R^{2}$ & 0.28 & 0.32 & 0.39 & 0.39 \\
\hline F-stat & 109.25 & 91.93 & 79.53 & 76.91 \\
\hline$N$ & 2427 & 2427 & 1513 & 1513 \\
\hline
\end{tabular}


Table 6

Relationship between Fund Holdings Relative to MSCI Weight and Country Attributes

This table shows results of OLS estimations of the determinants of country-level fund allocations, relative to the MSCI index. The dependent variable is \% Relative Spread:

$\%$ Relative Spread = (\% Fund's Portfolio in Country - \% MSCI Index weight for Country)

The country attributes examined are log of GDP per capita in US dollars (LGDPPC), exchange rate regime (EXRATE), market capitalization to GDP (MKTCAPGDP), market return (MKTRETURN), market turnover (TURNOVER), legal framework (LEGALITY), shareholder rights (SHRIGHTS), and accounting standards (ACCOUNT). Macroeconomic indicators are from the IMF-IFS database. Exchange rate regime (EXRATE) is from Reinhart and Rogoff (2003). ACCOUNT and SHRIGHTS ("anti-director rights") are from La Porta et al. (1998) and Pistor (2000). LEGALITY is an index constructed by Berkowitz, Pistor and Richard (2002) to measure the strength of the legal system. Market characteristics are from Datastream. t-statistics are in parenthesis. $* *$ and $*$ indicate significance at the 5 percent and 10 percent level, respectively.

\begin{tabular}{|c|c|c|c|c|}
\hline INTERCEPT & $\begin{array}{c}-1.56 \\
(-1.15)\end{array}$ & $\begin{array}{c}0.16 \\
(0.10)\end{array}$ & $\begin{array}{c}1.38 \\
(0.77)\end{array}$ & $\begin{array}{c}-6.90 * * \\
(-2.01)\end{array}$ \\
\hline$L G D P P C$ & $\begin{array}{c}0.18 \\
(1.17)\end{array}$ & $\begin{array}{l}-0.02 \\
(0.12)\end{array}$ & $\begin{array}{c}-1.41 * * \\
(-5.66)\end{array}$ & $\begin{array}{l}0.63 * \\
(1.73)\end{array}$ \\
\hline$E X R A T E$ & $\begin{array}{c}0.45 * * \\
(6.36)\end{array}$ & $\begin{array}{c}0.53 * * \\
(7.62)\end{array}$ & $\begin{array}{c}0.32 * * \\
(2.95)\end{array}$ & $\begin{array}{c}0.17 \\
(1.27)\end{array}$ \\
\hline MKTCAPGDP & $\begin{array}{l}-0.03 * * \\
(-12.03)\end{array}$ & $\begin{array}{l}-0.03 * * \\
(-11.57)\end{array}$ & $\begin{array}{c}0.00 \\
(0.19)\end{array}$ & $\begin{array}{c}-0.03 * * \\
(-9.80)\end{array}$ \\
\hline MKTRETURN & - & $\begin{array}{l}0.01 * * \\
(3.62)\end{array}$ & $\begin{array}{l}0.01 * \\
(1.81)\end{array}$ & $\begin{array}{c}0.02 * * \\
(2.34)\end{array}$ \\
\hline TURNOVER & - & $\begin{array}{c}-0.00 * * \\
(-3.94)\end{array}$ & $\begin{array}{c}-0.00 \\
(-1.44)\end{array}$ & $\begin{array}{c}-0.00 \\
(-0.94)\end{array}$ \\
\hline ACCOUNT & - & - & $\begin{array}{c}0.25 * * \\
(8.67)\end{array}$ & $\begin{array}{c}0.14 * * \\
(2.39)\end{array}$ \\
\hline SHRIGHTS & - & - & $\begin{array}{l}3.55^{* * *} \\
(8.08)\end{array}$ & - \\
\hline $\begin{array}{l}\text { ACCOUNT* } \\
\text { SHRIGHTS }\end{array}$ & - & - & $\begin{array}{c}-0.08 * * \\
(-8.22)\end{array}$ & - \\
\hline$L E G A L I T Y$ & - & - & - & $\begin{array}{c}-0.05 \\
(-0.18)\end{array}$ \\
\hline $\begin{array}{l}\text { ACCOUNT* } \\
L E G A L I T Y\end{array}$ & - & - & - & $\begin{array}{c}-0.01 \\
(-1.26)\end{array}$ \\
\hline$R^{2}$ & 0.07 & 0.08 & 0.12 & 0.11 \\
\hline F-stat & 74.07 & 46.46 & 32.97 & 29.24 \\
\hline$N$ & 2402 & 2402 & 1513 & 1513 \\
\hline
\end{tabular}


Table 7

\section{Characteristics of Firms in Fund Portfolios Relative to Worldscope}

The table compares firm characteristics of three Groups of firms: Group 1 consists of all firms in Worldscope for emerging market countries in our sample; Group 2 consists of Worldscope firms in Group 1 that are not included in the portfolio holdings of any mutual funds; and Group 3 consists of firms in Group 1 that are in included in the portfolio holdings of at least one fund. Median values are reported for market capitalization (MVALUE) in millions of U.S. \$, total assets in million of U.S.\$ (ASSETS), total debt/total capital (TDTCAP), the ratio of market price to book value (PB), return on equity (ROE), return on assets (ROA), total stock return in past 12-months (TRETURN), dividend yield (DYIELD), percentage float (FLOAT), an index of accounting standards, auditor quality, auditor opinion, and reporting of consolidated statements, (ACQUALITY), which can have values between 0 (weakest) to 4 (strongest), the number of analysts that follow a firm (NANALYSTS), the percentage of firms with a listed and unlisted ADR (\% ADR Firms) and percentage of firms with only a listed ADR on NYSE, Nasdaq or AMEX (\% Listed ADR Firms). Firm financial characteristics and ACQUALITY are from Worldscope, NANALYSTS is from IBES, and ADR information is from the Bank of NY (BONY) website.

\begin{tabular}{|c|c|c|c|}
\hline & $\begin{array}{c}\text { Group1 } \\
\text { Worldscope } \\
\text { N=4138 } \\
\text { Median } \\
\end{array}$ & $\begin{array}{c}\text { Group 2 } \\
\text { Funds Invested =0 } \\
\mathbf{N}=\mathbf{2 8 3 1} \\
\text { Median } \\
\end{array}$ & $\begin{array}{c}\text { Group 3 } \\
\text { Funds Invested =1 } \\
\mathbf{N}=\mathbf{1 3 0 7} \\
\text { Median }\end{array}$ \\
\hline $\begin{array}{l}\text { MVALUE } \\
\text { (thousand US\$) }\end{array}$ & 71,937 & 38,993 & 255,507 \\
\hline $\begin{array}{l}\text { ASSETS } \\
\text { (thousand US\$) }\end{array}$ & 171,886 & 96,506 & 634,956 \\
\hline FLOAT (\%) & 45.73 & 44.28 & 48.97 \\
\hline NANALYSTS (\#) & 1 & 1 & 4 \\
\hline ACQUALITY & 2 & 2 & 2 \\
\hline$\%$ ADR Firms & 13 & 6 & 28 \\
\hline \% Listed ADR Firms & 4 & 1 & 10 \\
\hline TDTCAP (\%) & 31.09 & 28.19 & 35.87 \\
\hline ROE (\%) & 7.79 & 6.60 & 9.67 \\
\hline$R O A(\%)$ & 4.79 & 4.39 & 5.58 \\
\hline DYIELD (\%) & 0.50 & 0 & 1.51 \\
\hline TRETURN (\%) & -15.53 & -12.52 & -19.63 \\
\hline$P B$ & 0.87 & 0.83 & 0.93 \\
\hline
\end{tabular}


Table 8

Correlations between Firm Attributes

This table shows correlations between firm characteristics. Log of market capitalization (LMVALUE) in thousands of U.S. \$, log of total assets in thousands of U.S.\$ (LASSETS), percentage float (FLOAT), the number of analysts that follow a firm (NANALYSTS), an index of accounting standards, auditor quality, auditor opinion, and reporting of consolidated statements, (ACQUALITY), which can have values between 0 (weakest) to 4 (strongest), an ADR dummy (ADR), total debt/total capital (TDTCAP), return on equity (ROE), return on assets (ROA), total stock return in past 12-months (TRETURN), dividend yield (DYIELD) and the ratio of market price to book value (PB). Firm financial characteristics and ACQUALITY are from Worldscope. NANALYSTS is from IBES, and ADR information is from the Bank of NY (BONY) website. ${ }^{* *}$ and * indicate significance at the 5 percent and 10 percent level, respectively.

\begin{tabular}{|c|c|c|c|c|c|c|c|c|c|c|c|}
\hline & LMVALUEUSD & FLOAT & NANALYSTS & ACQUALITY & TDTCAP & ROE & DYIELD & $A D R$ & TRETURN & $P B$ & LASSETS \\
\hline LMVALUE & 1.00 & 0.02 & $0.49 * *$ & $0.19^{* *}$ & $-0.07 * *$ & $0.26^{* *}$ & $0.04 * *$ & $0.34 * *$ & $0.14 * *$ & $0.24 * *$ & $0.78^{* *}$ \\
\hline FLOAT & & 1.00 & -0.01 & $-0.05 * *$ & $0.06 * *$ & $-0.06^{* *}$ & $-0.04 * *$ & -0.02 & $-0.07 * *$ & $-0.07 * *$ & $0.09^{* *}$ \\
\hline NANALYSTS & & & 1.00 & $0.15^{* *}$ & 0.01 & $0.13^{* *}$ & $0.03 *$ & $0.30 * *$ & $-0.04 * *$ & $-0.06^{* *}$ & $0.43^{* *}$ \\
\hline ACQUALITY & & & & 1.00 & $-0.03 *$ & $0.05^{*}$ & $-0.05^{* *}$ & $0.07 * *$ & $0.04 * *$ & 0.01 & $0.13^{* *}$ \\
\hline TDTCAP & & & & & 1.00 & $-0.29 * *$ & $-0.18^{* *}$ & 0.02 & $-0.09^{* *}$ & -0.01 & $0.22 * *$ \\
\hline ROE & & & & & & 1.00 & $0.22 * *$ & 0.05 & $0.15^{* *}$ & $0.19 * *$ & $0.06^{* *}$ \\
\hline DYIELD & & & & & & & 1.00 & 0.00 & $0.07 * *$ & -0.15 & $0.06^{* *}$ \\
\hline$A D R$ & & & & & & & & 1.00 & 0.01 & 0.00 & $0.33^{* *}$ \\
\hline TRETURN & & & & & & & & & 1.00 & 0.04 & -0.01 \\
\hline$P B$ & & & & & & & & & & 1.00 & $-0.11^{* *}$ \\
\hline LASSETS & & & & & & & & & & & 1.00 \\
\hline
\end{tabular}


Table 9

\section{Logit Models of Fund Holdings and Firm Characteristics}

This table shows results of logit estimations of the determinants of firm-level fund holdings. The dependent variable in each of the models is a dummy variable equal to one if the fund invests in the firm and zero otherwise. All firms in emerging markets covered by Worldscope are used in the analysis. The country-level explanatory variables are log of GDP per capita (LGDPPC), exchange rate regime (EXRATE) and market capitalization (MKTCAPGDP). Firm-level independent variables are log value of market capitalization in US\$ (LMVALUEUSD), log of total assets in US\$ (LASSETS), total stock return in past 12-months (TRETURN), dividend yield (DYIELD), total debt/total capital (TDTCAP), ROE, price to book (PB), analyst following as reported by IBES (NANALYSTS), ADRLIST dummy equals one if it is a listed ADR (ADR), ADRUNLIST dummy equals one if it is an unlisted ADR (ADRUNLIST), and accounting quality (ACQUALITY). Macroeconomic indicators are from the IMF-IFS and exchange rate regime (EXRATE) is from Reinhart and Rogoff (2003). Firm-level market data are from Datastream. Firm financial characteristics and ACQUALITY are from Worldscope. ADR information is from the Bank of NY (BONY) website. Industry dummy variables are included in all models. Z-statistic is in parenthesis. ${ }^{* *}$ and $*$ indicate significant at the 5 percent and 10 percent level, respectively.

\begin{tabular}{|c|c|c|c|}
\hline INTERCEPT & $\begin{array}{l}.-9.30^{* *} \\
(-11.55)\end{array}$ & $\begin{array}{c}-9.16^{* *} \\
(-11.28)\end{array}$ & $\begin{array}{c}-9.26 * * \\
(-11.40)\end{array}$ \\
\hline LGDPPC & $\begin{array}{c}0.09 \\
(1.01)\end{array}$ & $\begin{array}{c}0.13 \\
(1.44)\end{array}$ & $\begin{array}{c}0.07 \\
(0.78)\end{array}$ \\
\hline EXRATE & $\begin{array}{c}0.00 \\
(0.01)\end{array}$ & $\begin{array}{c}-0.01 \\
(-0.11)\end{array}$ & $\begin{array}{c}0.01 \\
(0.18)\end{array}$ \\
\hline МKTCAPGDP & $\begin{array}{c}-0.01^{* *} \\
(-6.58)\end{array}$ & $\begin{array}{c}-0.01 * * \\
(-6.26)\end{array}$ & $\begin{array}{c}-0.01 * * \\
(-6.89)\end{array}$ \\
\hline DYIELD & $\begin{array}{c}0.00 \\
(0.44)\end{array}$ & $\begin{array}{c}0.01 \\
(0.69)\end{array}$ & $\begin{array}{c}0.00 \\
(0.48)\end{array}$ \\
\hline TDTCAP & $\begin{array}{c}-0.01^{* *} \\
(-2.32)\end{array}$ & $\begin{array}{l}-0.00^{*} \\
(-1.96)\end{array}$ & $\begin{array}{c}-0.00 * * \\
(-2.17)\end{array}$ \\
\hline TRETURN & $\begin{array}{c}-0.00^{* *} \\
(-3.49)\end{array}$ & $\begin{array}{c}-0.00^{* *} \\
(-3.65)\end{array}$ & $\begin{array}{c}-0.00 * * \\
(-3.55)\end{array}$ \\
\hline ROE & $\begin{array}{c}0.00 \\
(0.22)\end{array}$ & $\begin{array}{c}0.00 \\
(0.14)\end{array}$ & $\begin{array}{c}0.00 \\
(0.22)\end{array}$ \\
\hline$P B$ & $\begin{array}{l}0.12^{* *} \\
(4.00)\end{array}$ & $\begin{array}{c}0.12 * * \\
(3.97)\end{array}$ & $\begin{array}{c}0.12 * * \\
(4.07)\end{array}$ \\
\hline LASSETS & $\begin{array}{l}0.64 * * \\
(17.07)\end{array}$ & $\begin{array}{l}0.59 * * \\
(17.07)\end{array}$ & $\begin{array}{l}0.64 * * \\
(16.92)\end{array}$ \\
\hline NANALYSTS & $\begin{array}{l}0.14^{* *} \\
(9.35)\end{array}$ & $\begin{array}{l}0.13 * * \\
(9.07)\end{array}$ & $\begin{array}{c}0.13 * * \\
(9.16)\end{array}$ \\
\hline ADRLIST & - & $\begin{array}{c}1.02 * * \\
(2.92)\end{array}$ & - \\
\hline ADRUNLIST & - & $\begin{array}{c}0.69 * * \\
(4.36)\end{array}$ & - \\
\hline ACQUALITY & - & - & $\begin{array}{l}0.10^{*} \\
(1.64)\end{array}$ \\
\hline Industry Dummies & included & included & included \\
\hline$N$ & 2721 & 2721 & 2696 \\
\hline$W A L D$ & 520 & 538 & 527 \\
\hline Pseudo $R^{2}$ & 0.29 & 0.30 & 0.29 \\
\hline Log Likelihood & -1288 & -1288 & -1278 \\
\hline
\end{tabular}


Table 10

\section{Percentage Fund Holdings and Firm Characteristics}

The dependent variable in each of the regression models is the mean proportion of fund's assets invested in the firm. All firms in emerging markets covered by Worldscope are used in the analysis. The country-level explanatory variables are log of GDP per capita (LGDPPC), exchange rate regime (EXRATE), market capitalization (MKTCAPGDP), countrylevel accounting standards (ACCOUNT), judicial efficiency (LEGALITY), and shareholder rights (SHRIGHTS). Firmlevel independent variables are log value of market capitalization in US\$ (LMVALUEUSD), log of total assets in US\$ (LASSETS), total stock return in past 12-months (TRETURN), dividend yield (DYIELD), total debt/total capital (TDTCAP), ROE, price to book (PB), analyst following as reported by IBES (NANALYSTS), ADR dummy (ADR), and accounting quality (ACQUALITY). Macroeconomic indicators are from the IMF-IFS; Exchange rate regime (EXRATE) is from Reinhart and Rogoff (2003); ACCOUNT and SHRIGHTS ("anti-director rights") are from La Porta et al. (1998) and Pistor (2000); and LEGALITY is an index constructed by Berkowitz, Pistor and Richard (2002) to measure the strength of the legal system. Country- and firm-level market data are from Datastream. Firm financial characteristics and ACQUALITY are from Worldscope. ADR information is from the Bank of NY (BONY) website. Industry dummy variables are included in all models. Appropriate variables have been winsorized and robust standard errors are estimated. $\mathrm{t}$-statistic is in parenthesis. $* *$ and $*$ indicate significant at the 5 percent and 10 percent level, respectively.

\begin{tabular}{|c|c|c|c|}
\hline $\begin{array}{l}\text { INTERCEPT } \\
\text { LGDPPC }\end{array}$ & $\begin{array}{c}-1.26^{* *} \\
(-3.96) \\
0.00 \\
(0.04)\end{array}$ & $\begin{array}{c}-1.12^{* *} \\
(-3.42) \\
0.01 \\
(0.27)\end{array}$ & $\begin{array}{c}-1.29^{* *} \\
(-3.85) \\
-0.18 \\
(-0.50)\end{array}$ \\
\hline MKTCAPGDP & $\begin{array}{c}-0.00^{* *} \\
(-3.43)\end{array}$ & $\begin{array}{l}-0.00 \\
(-1.59)\end{array}$ & $\begin{array}{c}-0.00 \\
(-0.79)\end{array}$ \\
\hline EXRATE & $\begin{array}{c}0.06 * * \\
(4.80)\end{array}$ & $\begin{array}{c}0.05^{* *} \\
(4.34)\end{array}$ & $\begin{array}{l}0.06^{* *} \\
(4.93)\end{array}$ \\
\hline DYIELD & $\begin{array}{l}-0.00^{*} \\
(-1.88)\end{array}$ & $\begin{array}{l}-0.00 \\
(-1.52)\end{array}$ & $\begin{array}{c}-0.00 * * \\
(-2.01)\end{array}$ \\
\hline TDTCAP & $\begin{array}{c}-0.00^{* * *} \\
(-4.55)\end{array}$ & $\begin{array}{l}-0.00^{* *} \\
(-4.18)\end{array}$ & $\begin{array}{c}-0.00^{* *} \\
(-4.84)\end{array}$ \\
\hline TRETURN & $\begin{array}{c}-0.00 \\
(-0.14)\end{array}$ & $\begin{array}{c}0.00 \\
(0.47)\end{array}$ & $\begin{array}{c}0.00 \\
(0.78)\end{array}$ \\
\hline ROE & $\begin{array}{c}-0.00 \\
(-0.06)\end{array}$ & $\begin{array}{c}0.00 \\
(0.13)\end{array}$ & $\begin{array}{c}-0.00 \\
(-0.29)\end{array}$ \\
\hline$P B$ & $\begin{array}{c}0.03^{* * *} \\
(3.62)\end{array}$ & $\begin{array}{c}0.03 * * \\
(3.55)\end{array}$ & $\begin{array}{l}0.03 * * \\
(3.72)\end{array}$ \\
\hline LASSETS & $\begin{array}{l}0.12 * * \\
(8.41)\end{array}$ & $\begin{array}{l}0.10^{* *} \\
(6.93)\end{array}$ & $\begin{array}{l}0.13^{* *} \\
(8.64)\end{array}$ \\
\hline NANALYSTS & $\begin{array}{c}0.03 * * \\
(5.14)\end{array}$ & $\begin{array}{c}0.02 * * \\
(4.32)\end{array}$ & $\begin{array}{l}0.03 * * \\
(5.09)\end{array}$ \\
\hline$A D R$ & - & $\begin{array}{c}0.71 * * \\
(3.87)\end{array}$ & - \\
\hline ACQUALITY & - & - & $\begin{array}{c}0.11 \\
(1.46)\end{array}$ \\
\hline SHRIGHTS & - & $\begin{array}{c}-0.00 \\
(-0.15)\end{array}$ & $\begin{array}{c}0.03 \\
(0.92)\end{array}$ \\
\hline $\begin{array}{l}\text { ADR * } \\
\text { SHRIGHTS }\end{array}$ & - & $\begin{array}{l}-0.09^{*} \\
(-1.83)\end{array}$ & - \\
\hline $\begin{array}{l}\text { ACQUALITY * } \\
\text { SHRIGHTS }\end{array}$ & - & - & $\begin{array}{c}-0.04 * * \\
(-1.94)\end{array}$ \\
\hline DASIA & $\begin{array}{l}0.64^{* *} \\
(4.49)\end{array}$ & $\begin{array}{l}0.61 * * \\
(4.32)\end{array}$ & $\begin{array}{l}0.54^{* *} \\
(3.81)\end{array}$ \\
\hline$D D I V$ & $\begin{array}{c}-0.03 \\
(-0.67)\end{array}$ & $\begin{array}{c}-0.03 \\
(-0.84)\end{array}$ & $\begin{array}{c}-0.04 \\
(-0.90)\end{array}$ \\
\hline Industry Dummies & included & included & included \\
\hline$N$ & 3403 & 3183 & 3156 \\
\hline $\operatorname{Adj} . R^{2}$ & 0.16 & 0.19 & 0.17 \\
\hline$F$ & 28.12 & 25.92 & 24.69 \\
\hline
\end{tabular}


Table 11

\section{Characteristics of Firms in Fund Portfolios Relative to MSCI}

The table compares firm characteristics of three Groups of firms: Group 1 consists of all firms in Worldscope for emerging market countries in our sample; Group 2 consists of Worldscope firms in Group 1 that are not included in the portfolio holdings of any mutual funds; and Group 3 consists of firms in Group 1 that are in included in the portfolio holdings of at least one fund. Median values are reported for market capitalization (MVALUE) in millions of U.S. \$, total assets in million of U.S.\$ (ASSETS), total debt/total capital (TDTCAP), the ratio of market price to book value (PB), return on equity (ROE), return on assets (ROA), total stock return in past 12-months (TRETURN), dividend yield (DYIELD), percentage float (FLOAT), an index of accounting standards, auditor quality, auditor opinion, and reporting of consolidated statements, (ACQUALITY), which can have values between 0 (weakest) to 4 (strongest), the number of analysts that follow a firm (NANALYSTS), the percentage of firms with a listed and unlisted ADR (\% ADR Firms) and percentage of firms with only a listed ADR on NYSE, Nasdaq or AMEX (\% Listed ADR Firms). Firm financial characteristics and ACQUALITY are from Worldscope, NANALYSTS is from IBES, and ADR information is from the Bank of NY (BONY) website.

\begin{tabular}{|c|c|c|c|}
\hline & $\begin{array}{c}\text { Group 1 } \\
\text { Funds Invested =1 } \\
\& \text { MSCI }=\mathbf{0} \\
\text { N=782 }\end{array}$ & $\begin{array}{c}\text { Group 2 } \\
\text { Funds Invested =1 } \\
\text { \& MSCI = 1 } \\
\text { N=525 }\end{array}$ & $\begin{array}{c}\text { Group 3 } \\
\text { Funds Invested =0 } \\
\text { \& MSCI }=1 \\
\text { N=124 }\end{array}$ \\
\hline $\begin{array}{l}\text { MVALUE } \\
\text { (million US\$) }\end{array}$ & 104,153 & 816,265 & 412,452 \\
\hline $\begin{array}{l}\text { ASSETS } \\
\text { (million US\$) }\end{array}$ & 368,236 & $1,429,126$ & 715,839 \\
\hline FLOAT (\%) & 48.95 & 49.03 & 49.00 \\
\hline NANALYSTS (\#) & 2 & 10 & 5 \\
\hline ACQUALITY & 2 & 2 & 2 \\
\hline$\%$ ADR Firms & 19 & 40 & 22 \\
\hline$\%$ Listed ADR Firms & 5 & 17 & 8 \\
\hline TDTCAP (\%) & 37.43 & 33.45 & 29.23 \\
\hline ROE (\%) & 7.17 & 12.65 & 11.82 \\
\hline$R O A(\%)$ & 4.52 & 6.92 & 7.03 \\
\hline DYIELD (\%) & 0.92 & 1.92 & 1.52 \\
\hline TRETURN (\%) & -23.70 & -14.41 & -14.99 \\
\hline$P B$ & 0.73 & 1.27 & 1.16 \\
\hline
\end{tabular}


Table 12

Percentage Fund Holdings Relative to MSCI Weight and Firm Characteristics

The dependent variable in each of the regression models is the \% Relative Spread:

$\%$ Relative Spread $=(\%$ Fund Allocation - \% MSCI Weight $)$

All firms in fund portfolios or in the MSCI index are used in the analysis. The country-level explanatory variables are log of GDP per capita (LGDPPC), exchange rate regime (EXRATE), market capitalization (MKTCAPGDP), country-level accounting standards (ACCOUNT), judicial efficiency (LEGALITY), and shareholder rights (SHRIGHTS). Firm-level independent variables are log value of market capitalization in US\$ (LMVALUEUSD), log of total assets in US\$ (LASSETS), total stock return in past 12-months (TRETURN), dividend yield (DYIELD), total debt/total capital (TDTCAP), ROE, price to book (PB), analyst following as reported by IBES (NANALYSTS), ADR dummy (ADR), and accounting quality (ACQUALITY). Macroeconomic indicators are from the IMF-IFS; Exchange rate regime (EXRATE) is from Reinhart and Rogoff (2003); ACCOUNT and SHRIGHTS ("anti-director rights") are from La Porta et al. (1998) and Pistor (2000); and LEGALITY is an index constructed by Berkowitz, Pistor and Richard (2002) to measure the strength of the legal system. Country- and firmlevel market data are from Datastream. Firm financial characteristics and ACQUALITY are from Worldscope. ADR information is from the Bank of NY (BONY) website. Industry dummy variables are included in all models. Appropriate variables have been winsorized and robust standard errors are estimated t-statistic is in parenthesis. ** and $*$ indicate significant at the 5 percent and 10 percent level, respectively.

\begin{tabular}{|c|c|c|c|}
\hline INTERCEPT & $\begin{array}{l}-0.88 \\
(-1.50)\end{array}$ & $\begin{array}{l}-1.15^{*} \\
(-1.86)\end{array}$ & $\begin{array}{c}-1.71 * * \\
(-2.64)\end{array}$ \\
\hline$L G D P P C$ & $\begin{array}{c}0.02 \\
(0.33)\end{array}$ & $\begin{array}{c}0.06 \\
(0.90)\end{array}$ & $\begin{array}{c}0.05 \\
(0.69)\end{array}$ \\
\hline МKTCAPGDP & $\begin{array}{c}-0.00 * * \\
(-2.13)\end{array}$ & $\begin{array}{l}-0.00^{*} \\
(-1.70)\end{array}$ & $\begin{array}{l}-0.00 \\
(-1.56)\end{array}$ \\
\hline EXRATE & $\begin{array}{l}0.06^{* *} \\
(2.30)\end{array}$ & $\begin{array}{c}0.06^{* *} \\
(2.41)\end{array}$ & $\begin{array}{l}0.08 * * \\
(3.32)\end{array}$ \\
\hline DYIELD & $\begin{array}{l}-0.01 \\
(-1.19)\end{array}$ & $\begin{array}{l}-0.01 \\
(-1.43)\end{array}$ & $\begin{array}{c}-0.00 \\
(-1.16)\end{array}$ \\
\hline TDTCAP & $\begin{array}{c}-0.00 * * \\
(-3.06)\end{array}$ & $\begin{array}{c}-0.00 * * \\
(-3.01)\end{array}$ & $\begin{array}{c}-0.01 * * \\
(-3.24)\end{array}$ \\
\hline TRETURN & $\begin{array}{c}0.00 \\
(0.19)\end{array}$ & $\begin{array}{c}0.00 \\
(0.33)\end{array}$ & $\begin{array}{c}0.00 \\
(0.56)\end{array}$ \\
\hline$R O E$ & $\begin{array}{c}0.00 \\
(1.52)\end{array}$ & $\begin{array}{c}0.00 \\
(1.22)\end{array}$ & $\begin{array}{c}0.00 \\
(0.83)\end{array}$ \\
\hline$P B$ & $\begin{array}{c}0.02 \\
(1.30)\end{array}$ & $\begin{array}{l}0.03^{*} \\
(1.79)\end{array}$ & $\begin{array}{l}0.03^{*} \\
(1.71)\end{array}$ \\
\hline LASSETS & $\begin{array}{l}0.10^{* *} \\
(4.06)\end{array}$ & $\begin{array}{l}0.09 * * \\
(3.15)\end{array}$ & $\begin{array}{l}0.10^{* *} \\
(4.03)\end{array}$ \\
\hline NANALYSTS & $\begin{array}{l}0.01 * * \\
(2.52)\end{array}$ & $\begin{array}{c}0.11 * * \\
(2.28)\end{array}$ & $\begin{array}{l}0.01 * * \\
(2.66)\end{array}$ \\
\hline$A D R$ & - & $\begin{array}{l}0.12 \\
0.53\end{array}$ & - \\
\hline ACQUALITY & - & - & $\begin{array}{c}0.25^{* *} \\
(1.98)\end{array}$ \\
\hline SHRIGHTS & - & $\begin{array}{c}-0.01 \\
(-0.14)\end{array}$ & $\begin{array}{l}0.14^{*} \\
(1.69)\end{array}$ \\
\hline $\begin{array}{l}\text { ADR * } \\
\text { SHRIGHTS }\end{array}$ & - & $\begin{array}{c}0.03 \\
(0.42)\end{array}$ & - \\
\hline $\begin{array}{l}\text { ACQUALITY * } \\
\text { SHRIGHTS }\end{array}$ & - & - & $\begin{array}{c}-0.07 * * \\
(-2.01)\end{array}$ \\
\hline Industry Dummies & included & included & included \\
\hline$N$ & 1674 & 1564 & 1556 \\
\hline $\operatorname{Adj} . R^{2}$ & 0.03 & 0.05 & 0.06 \\
\hline$F$ & 5.01 & 5.02 & 5.59 \\
\hline
\end{tabular}

